\title{
The FOMC in 1983-84: Setting Policy in an Uncertain World
}

\author{
R. W. Hafer
}

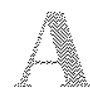
Open Market Committee (FOMC) meetings during 1983 and 1984 , two issues pervade the discussions. One is the effect of new financial innovations on the measurement of the monetary aggregates, especially M1. The uncertain impact of such innovations can be viewed as the underlying reason for reducing the weight atfached to $M 1$ in favor of the broader aggregates, M2 and M3. 'This action, taken in October 1982, continued to hold throughout 1983 and through the first part of 1984 .

The other major issue throughout the two years was the economic recovery. Concern focused initially on the emerging possibility of the recovery and later on the strength and depth of the expansion. Because of these uncertainties, policy implementation involved increased attention to recent economic developments. This sensitivity to economic developments was heightened by uncertainties arising from both the divergence of the relationship of $M 1$ and M2 to GNP the income velocity of each monetary measure - from historical patterns and concern about the influence of recent financial innovations on velocity. Later, uncertainty persisted because the economy was expanding more rapidly than expected and little upward movement in the rate of inflation was evident. Moreover, the size of the federal budget deficit and its presumed interest rate effects were viewed as a menace to a continuing economic expansion and a burden to the setting of a non inflationary monetary policy.

R. W. Hater is a research officer at the Federal Reserve Bank of St. Louis. Lary J. DiMariano provided research assistance.
The purpose of this article is to provide a chronological examination of the Federal Open Market Committee's (hereafter "Committee's") policy decisions during the $1983-84$ period. ${ }^{.}$In doing so, we shall attempt to summarize the numerous factors influencing the setting of its long- and short-run monetary policy objectives.

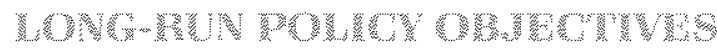

Under the requirements set forth in the Full Em ployment and Balanced Growh Act of 1978, also known as the Humphrey-Hawkins Act, the Committee must transmit to Congress reports on its objectives for annual monetary and credit growth targets. These reports are submitted twice a year, in February and again in July. The February report discusses the Committee's annual growth rate largets for the current calendar year, typicaly expressed as a growth rate range from the fourth quarter of the previous year to the fourth quarter of the current year. At the July

NOTE: Citations referred to as "Fecord" are to the "Record of Policy Actions of the Federal Open Market Committee" found in various issues of the Federal Reserve Bulletin. Citations referred to as "Report" are to the "Monetary Policy Report to the Congress," also found in various issues of the Bulletin.

1For a description of the FOMC's membership during 1983-84, see the insert on $p$. 16 of this issue.

${ }^{2}$ The use of fouth-quarter-fo-fourth-quarter target ranges recuces the problem of base drifi. Before the use of these set annual targets, the Committee would establish an annual money growth target each quarter, Thus, the base of the new annual target would "drift" during the calendar year depending on whether actual money growth in any one quarter was above or below the existing target range. It should be noted, however, that the current procedure does not elminate base dritt from one calendar year to the next. 


\section{Organization of the Committee in 1983-84}

The Federal Open Market Committee FOMC, consists of 12 members: the seven nembers of the federal heserve Board of Governors and five of the 12 Federal Re. serve Rank presilients. The Ghatmon of the Board of Governors is, by tradition, also chaiman of the Commit tee. The president of the New York Federal Reserve Bank is, also by tradition, its vice chairman, All Federal heserve Bank prosidents attend Committee meetings and present their views, but only those presidents who are nembers of the Committee may vote. Four memberships rotate among Bank presidents and are held for one-year terms beginning March ? of each year, ihe president of the New York Federal Reserve Bank is a permanent vot ing nember of the Committee

Members of the board of Governors at the beginning of 1983 included Chairman Paul A. Volcker, Preston Martin, Henry C. Wallich, J. Charles Partee, Nancy It. Teeters, Emmett I Rice and Lyle E. Gramley Govemor Teeters term expired on January 31,1984 , and in July 1984 , she was replaced by Martha $\mathbf{R}$. Seger. The following presi dents served on the Committee during January and February 1983. Anthony M. Solomon INeW Vorkl, Iohn I Balles (San Trancisco), Robert P Black (Richmond, Wil lian F Ford Atlantal and Karen N. Horn (Cleveland, The Cormittee membership changed in March 1983 and the four rotating positions woro fllod by, Rogor Cuffoy I Kan sas City, Silas Keehn (Chicago), Frank E. Momis Boston), and Theodore 11 . Roberts (St, Louis) ' The Committee nembership changed again in March 1984 and the four

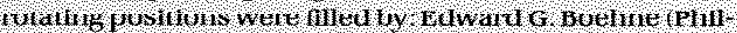
adelphial, Robert 14 Boykin Dallas, Karen N. Horn (Cleveland), and E, Gerald Corrigan Minneapolis).

Ine L ommitee met eight times at regularly scheduled meetings during 1983 and during 1984 to discuss, among other things, economic lrends and to decide upon the future course of open market operations, As in previous years, however. lelephone or telegram consultations were held occasionally between scheduled meetings. During each regulanly scheduled neeting, a directive Was issued to the Federal Resene Bank of New York. Each directive contained a short review of economic developments, the general economic goals sought by the Committee, the Committee s long run monetary growth objectives, and instructions to the Managor of the Systom Open Market Account at the New York Bank for the conduct of open market operations. These instructions typically were stated in terms of the reserve conditions

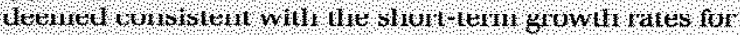
M1 and M2 that were considered in tum to be consistent with desired longer-run growth rates of the monetary aggregates?' The Commitee also speciffed intermeeting ranges for the tederal funds rate. These ranges provide a mechanism for initiating consultations between meet ings whenever it appears that the constraint of the fed eral funds rate is proving inconsistent with the objectives for the behavior of the monetary aggregates.

The Account Manager has the major responsibility for formulating plans regarding the timing, types and amount of daily buying and selling of securities in fulfilling the Committee's directive, Each morning the Man ager and his staff plan the open market operations for that day, This plan is developed on the basis of the Committee's directive and the latest developments af ferting money and credit market conditinns, growth af the monetary aggregates and bank reserve conditions. The Manager also consults with staff at the Board of Govemors. Present market conditions and open market opcrations that the Manager proposes to execute each day are discussed that moming in a telephone confer ence call involving staff at the New York Bank, the Board and one voting president. Other nembers of the Com, mitree are nformed of the daly plan by nternal nemo or wire.

The directives issued by the Committee and a sum mary of the reasons for the Committee actions are pub. lished in the "Record of Policy Actions of the Federal Open Market Committee. 'The 'Record' for each meeting is released a few days after the following Committee necting, Soon after its reloase, it appears in the rederal Reserve Bulletin. In addition, 'Records' for the entire year are published in the annual report of the Board of Governors. The "Record' for each neeting during $198 \%$ and 1984 included:

1) a staff summary of recent economic developments - such as changes in prices, employment, indus: trial prodiction and components of the national income accounts - and projections of general price, output and employment developments for the year ahead.

21 a summary of recent international financial developments and the US foreign trade balance;

3) a summary of open market operations, growth of the monetaly aggregates and banl reserves, and money market conditions since the previous meeting:

4) a summary of the Committee's discussion of cur rent and prospective economic and financial con ditions and the current policy considerations, in cluding money market conditions and the movement of monetary aggregates:

51 decisions of the Committee;

6) a policy directive issued by the Committee to the Federal Reserve Bank of New York:

71 a list of the members' votes and any dissenting comments; and

8) a description of any actions regarding the Commit

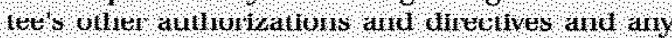
actions or consultations that may have occurred between the regularly scheduled meetings.

Theodore $H$ Roberts took office as president of the St Louis Bank on February 1, 1983, replacing Lawrence K Roos

2No formal meetings were held in January, Apri, June and September 1083 In 1084, no formal mootings wore hold in Fobruary Apri, June and September.

BDuring 1983 and the first half of 1984 , short run objectives for M1 were stated in terms of a monitoring range. During this period. short run objoctivos woro sel for M2 and M3. Also, a monitoring range was established for total debt of the domestic nonfinancial sector 
meeting and in its midyear report to Congress, the Committee reviews its progress toward achieving these goals. At this meeting it also establishes tentative growth rate ranges for the following calendar year.

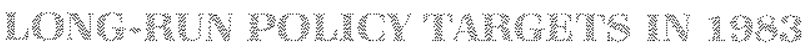

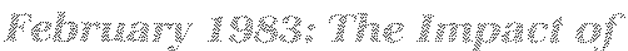

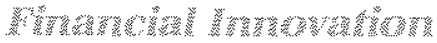

In establishing the 1983 growth rate ranges at its February 1983 meeting, the Committee faced a situation in which the money-income relationship during 1982 had deviated substantially from historical norms. Moreover, there was concern about the possibility that these relationships would continue to change during 1983.

The cause of this concern was the significant decline in the income velocity of both M1 and M2 in 1982 For example, from the fourth quarter of 1981 to the fourth quarter of $1982, \mathrm{M1}$ velocity fell at a 5.6 percent rate and $\mathrm{M} 2$ velocity declined at a 6.2 percent rate. In both instances, this prolonged decline in velocity was unprecedented since the $1950 \mathrm{~s}^{3}$

Concern about the unpredictability of velocity was related to a number of institutional developments that transpired in 1982. These developments were the large volume of maturing all-savers certificates beginning in October, the introduction on December 14 of money market deposit accounts (MMDAs) and the availability of Super NOW accounts beginning January $5_{z} 1983$. It was believed that these new accounts would blur the historical distinction between $\mathrm{M} 1$ and non $\mathrm{M} 1$ balances, that is, between balances held primarily for transaction purposes and those held for savings. Consequently, the Committee decided at its October 1982 meeting to attach less weight in making policy decisions on the behavior of M1 and rely more on the behavior of $\mathrm{M} 2$ and $\mathrm{M} 3{ }^{4}{ }^{4}$

Following this decision, the Committee set only a tentative 1983 "monitoring" range for M1. This range was set at 4 to 8 percent for the period from IV/1982 to

\footnotetext{
Numerous studies have appeared recently attempting to explain the recent behavior of velocity. Explanations for the large decline in $\mathrm{M} 1$ velocity include a significant reduction in intlationary expectations (Keran (1984)), the decline in inflation and nominal interest rates (Judd (1983)), the cyclical response of velocity to a lengthy and severe recession (Tatom (1983)), and the effect of the introduction of new accounts in late 1982 and early 1983 , which led to sharp increases in the growth of $\mathrm{M} 1$ and, therefore, temporarily distorted the observed behavior of velocity (Hafer (1984)).
}

4 See Thornton (1983a) for a full discussion of this decision.
V/1983 (see table 1). Although higher and wider than the 1983 target growth range established at the July 1982 meeting (2.5 percent to 5.5 percent), the new monitoring range reflected a slowing from the actual M1 growth of 8.7 percent for 1982.

The setting of this relatively wide range reflected most Committee members' concern about M1's future relationship with GNP because of the introduction of new deposit accounts. Dissenting from the majority vote, however, Presidents Black and Horn argued that more policy weight should be given to M1. In this regard they expressed the opinion that M1 "was more reliably related to the Committee's ultimate economic objectives than were the broader aggregates" and that it was more controllable. ${ }^{s}$ In the end, however, the majority of the Committee voted to monitor the behavior of M1 and evaluate its appropriate policy weight in light of incoming evidence about the behavior of M1 velocity.

In setting the 1983 growth target for M2, the Com" mittee voted for a range of 7 to 10 percent. Breaking from the use of a fourth-quarter-to-fourth-quarter period, the $\mathrm{M} 2$ growth range for 1983 uses the February March average as the base period (see table 1). This change was made because of the surge of funds in late 1982 and early 1983 into the new MMDA accounts from sources not currently included in M2.

For example, by the end of 1982, MMDAs outstanding had increased to about $\$ 87$ billion and, by the end of January 1983 , to about $\$ 230$ billion. It was expected, however, that this influx of funds into MMDAs from non-M2 assets would run its course by March. Thus, the February-March base period was used to minimize the distortions associated with banks' aggressive campaigns for the new MMDA accounts that occurred since their mid-December introduction. Moreover, although the 7 to 10 percent range for 1983 was higher than the tentative 6 to 9 percent range established at the July 1982 meeting, this growth path was judged to represent about the same growth for the year as a whole, once the distortions from the new accounts were considered.

The 1983 growth range for $\mathrm{M} 3$ was set at 6.5 to 9.5 percent, identical to its 1982 range (see table 1). This range reflected a reduction from $M 3$ 's actual growth in 1982, about a 10 percent rate. Moreover, the Committee generally assumed that the new deposit accounts would have only a minor impact on the behavior of M3.

sRecord (Apin 1983), p. 290. 
Table 1

\section{FOMC Long-Run Operating Ranges}

\begin{tabular}{|c|c|c|c|c|}
\hline \multirow[b]{2}{*}{ Date or meeting } & \multirow[b]{2}{*}{ Target period } & \multicolumn{3}{|c|}{ Ranges } \\
\hline & & Mi & in & no \\
\hline February $8.9,1983$ & 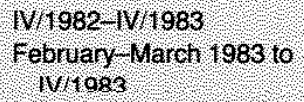 & ientative $4-8 \%$ & $7-10 \%$ & $6.5 .9 .5 \%$ \\
\hline July $12-13,1983^{2}$ & $\begin{array}{l}\text { W/1982-N/ } 1983 \\
\text { February March } 1983 \text { to } \\
\text { W/1983 } \\
\text { W1983- V/1983 }\end{array}$ & $\frac{4.9}{5.9 \%}$ & $\begin{array}{l}\text { reafirmed } \\
\text { above range }\end{array}$ & $\begin{array}{l}\text { reaffirned } \\
\text { above range }\end{array}$ \\
\hline January $30-31,1984^{\circ}$ & V/1983-IV/1984 & $4.8 \%$ & $6-9 \%$ & $6.9 \%$ \\
\hline July $16-17,1984$ & V/1983-IV/1984 & $\begin{array}{l}\text { reaffirmed } \\
\text { above range }\end{array}$ & $\begin{array}{l}\text { reatfimed } \\
\text { above range }\end{array}$ & $\begin{array}{l}\text { reafirmed } \\
\text { above range }\end{array}$ \\
\hline
\end{tabular}

Dissents:

Mi. Black and Mro. Horn dicoontod from thic action booauco thoy protorrod to givo moro woight to Mit ao a polioy objootivo. Whilo recognizing the difficuties in interpreting Mi currenty, they believed that over time Mt was more reliably related to the Committee's utimate economic objectives than were the broader aggregates and that it constituted a better basis for setting appropriate paths for reserve growth. They also favored reemphasizing $M$ i because they viewed it as a more controllable aggregate. In addition, Mr. Black indicated that he saw a need for lower target ranges, but he wanted to reduce monetary expansion cradually to avert dislocative effects.

Mr. Ford dissented because he believed that policy should focus more firmly on mplementing nonintlationary growth via a smaller number of monetary targets. He also saw an urgent need to begin gradually reducing the rate of monetary growth in light of its inflationary potential, particularly when complemented by highty stimulative fiscal policy. He felt strongly that this combination of policies ran the risk of triggering another short-lived recovery that might be aborted in 1984 by a private credit shortage and the return of high inflation and interest Taltes:

Mi. Walich favored some what lower monetary growth ranges for 1983, which in his view would be more consistent with the objectives of fostering economic recovery while mininizing the risks of stimulating inilation.

Mr. Morris dissented from this action because he did not believe that target ranges should be set for M1 and M2. Because of financial

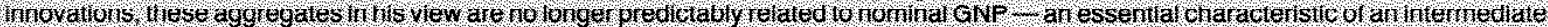
target for monetary policy. Thus, the Committee should tum to broader financial aggregates, specifically M3, totallicuid assets, and total domestic nonfinancial debt as targets for monetary policy.

3Mr. Morris dissented from this action because he believed that regulatory changes and financial innovations had made M1, M2, and M3 unsuitable targets for monetary policy since, in nis vew, they were no longer prealctably related to nominal GiNP. Accordingly he preferred to focus on total domestic nonfinancial debt and total liquid assets as intermediate targets for monetary policy.

Also at this meeting the Committee agreed to establish a monitoring range for the growth of the total debt of domestic nonfinancial sectors. The consensus was to establish a growth range of 8.5 to 11.5 percent for the period from fourth quarter 1982 to fourth quarter 1983. The Committee hoped that the debt measure would provide an alternative piece of information that it might use in assessing developments in the targeted monetary aggregates. ${ }^{6}$

Eqbid., p. 289. The usefulness of this broad debt measure was argued in a series of articles by Benjamin Friedman $(1981,1982,1983)$. Fusther support for this detit rieasure was presentied in Kupcke (1983) and Morris $(1982,1983)$. Other studies have demonstrated that the relationship between the behavior of debt and economic activity makes debt a dubious candidate for an intermediate target. See Hafer (1984. 1985). Porter and Offenbacher (1983) and Davidson and Hafer (1983).

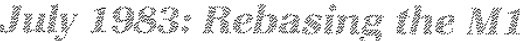

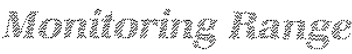

As shown in table 1, the Committee reaffirmed its 7 to 10 percent growth range for M2 (using a FebruaryMarch 1983 base period) and its 6.5 to 9.5 percent range for M3 at its midyear review. For 1984, the tentative ranges for M2 and M3 were reduced 0.5 percentage points. Thus, measured from IV/1983 to IV/1984, the tentative growth range for $\mathrm{M} 2$ was set at 6.5 to $y .5$ percent and at 6 to 9 percent for M3. In setting these ranges, it was argued that the distortions caused by the shifting of non-M2 funds in to MMD, $\triangle \mathrm{s}$ oarlior in the year had ceased to be significant. Also, the Committee reaffirmed the 1983 range for total debt and established a tentative 1984 growth range one-half percentage point lower at 8 to 11 percent. 
Table 2

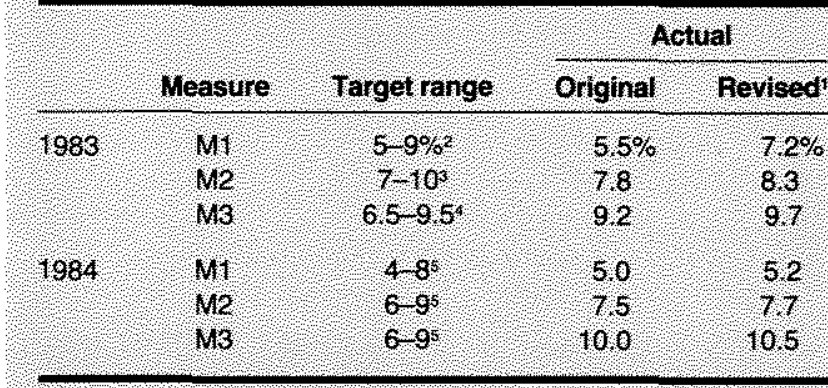

The data for 1983 represent revisions as of February 1984 These revisions holude adust ments for benchmark changes and Include tem Eurodollars held by US residenis In Canada and the United Kingdon and a foretgn branches of US banks elsewhere. The revised data for 1984 are based on data avallable in February 1985 .

Target period is 111983 to 1 V1983.

Target peried is February-March 1983 to W/983

Trarget period is N/1982 W/1983.

TTarget period Is W/1983-1V/984.
Actual and Desired Money Growth alterations in seasonal factors. Also, W3 was changed in 1984 to

would clarify to the public the fact that the expansive growth of M1 during late 1982 and early 1983 was a function of special financial innovations and not a policy decision. Thus, by rebasing to II/1983, the Committee wished to emphasize the point that it expected and desired slower M1 growth.

With the base period set at II/1983, the Committee established a 5 to 9 percent growth monitoring range for M1 ending in N/1983. Moreover, it also decided to establish a tentative monitoring range of 4 to 8 percent growth for the period from IV/1983 to IV/1984.

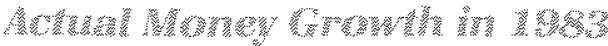

Table 2 reports both the target ranges and actual growth rates for M1, M2 and M3 in 1983. The actual growth rates reported use the original data and data that reflect the 1984 benchmark and seasonal adjustment revisions. Also, the M3 revision captures some changes in its definition.

The data reported in table 2 indicate that the actual growth of $\mathrm{M} 1$ and $\mathrm{M} 2$ during 1983 were within the targeted growth ranges set by the Committee. M3's original growth rate of 9.2 percent was at the upper bound of the range established for the year. Revisions and the definitional change increased its growth slightly, pushing the actual growth rate to 9.7 percent, just above the 9.5 percent targeted upper bound for the year.

ing 1982 and early 1983 were abating. To some extent the Committee recognized that factors influencing $\mathrm{M} 1$ velocity (and, therefore, M1 demand) during the pre* ceding year probably were beginning to wane:

As the upward impact on M1 demand of earlier interest rate declines has faded and a sizable buildup in liquid balances has taken place, it seems probable that some pickup in the velocity of M1 will develop over the quarters ahead, in closer conformance with cyclical and secular patterns of earlier years.:

Though it appeared that the relationship between M1 and GNP was returning to its historical nomm, uncertainty remained about the changing nature of the M1 measure. That is, to the extent that M1 reflected both transaction demands and the "savings propensities of the public," the behavion of the current measure of $\mathrm{M} 1$ relative to economic activity remained unclear.

In light of these doubts, two actions were taken: First, the Committee agreed to retain the current weighting structure of the monetary aggregates in the formation of policy. Second, it decided to rebase the 1983 M1 growth range from IV/1982 to IL/1983. The Committee agreed that rebasing $\mathrm{M} 1$ growth ranges

${ }^{7}$ Report (August 1983), p. 582

\section{晋

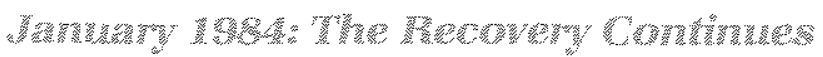

At its January 30-31, 1984, meeting, the Committee reviewed the tentative growth ranges lestablished in July 1983 ) for the monetary aggregates. Although the economic recond of 1983 indicated that a substantial recovery from the 1981-82 recession was under way, concerns over the sustainability of the current expansion and the breadth of the economic advance into

BFrank Morris, president of the Federal Reserve Bank of Boston, dissented from this action on the grounds that both $\mathrm{M} 1$ and $\mathrm{M} 2$ were unreliable measures to be used as intermediate targets for policy. Instead, he argued for increased emphasis on M3, L and total nonfinancial debt in policy discussions.

SSee Appendix $B$ to Report (February 1984).

1 Staff projections presented at this meeting indicated that real GNP growth in 1984 would be moderate. Also, the centrat tendency of Committee members' torecasts tor real GNP in 1984, measured on a IV/1983 to IV/1984 basis, was 4 to 4.75 percent, reflecting some slowing from the actual 6 percent growth rate in 1983 . 1984 remained." 
With the possible impact of unprecedented federal budget deficits, the rising foreign value of the dollar and a growing imbalance between our exports and imports viewed as threats to the current expansion, Committee members argued at this meeting that the monetary growth ranges set for 1984 should promote a long-lasting expansion along with a continuing control of inflation. As shown in table 1, the ranges established for the period from IV/1983 to IV/1984 were as follows: a 4 to 8 percent growth range for M1; 6 to 9 percent for $M 2 ; 6$ to 9 percent for $M 3$; and 8 to 11 percent for total domestic nonfinancial debt. ${ }^{t 1}$

At this meeting there also was some discussion about the relative weight to be given to $\mathrm{M} 1$ in implementing policy. The growth of $\mathrm{M} 1$ velocity had begun to return to "nomal," expanding at a 5.4 percent rate in IV/1983. Given M1's recent behavior, "one member urged placing primary emphasis on $\mathrm{M} 1$ " and "a number of other members supported giving M1 greater weight, if not primary emphasis, in light of what they viewed as the emergence of a more predictable pattern in its velocity."

Other members viewed M1's future behavior in relation to GNP as uncertain cue to the increased proportion of M1 accounted for by interest-bearing NOW and Super NOW deposits. Because of the perceived difficulties in predicting the public's reaction to changes in the economic environment - especially the interest elasticity of these new accounts - the policy usefulness of $M 1$ remained questionable. Thus, it was agreed "for the time being" that "substantial weight" would continue to be placed on the behavior of $\mathrm{M} 2$ and $\mathrm{M3}$, relative to $\mathrm{M}$ and total domestic nonfinancial debt, in implementing policy.

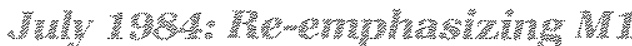

During the first half of 1984, the M1 and M2 aggregates behaved in a manner consistent with the Committee's objectives established at its January meeting. Although some concern remained about the measurement of the public's demand for $\mathrm{M1}$, the ranges established previously for 1984 were reaffirmed (see table 1 ). Although $\mathrm{M} 3$ and total debt increased at rates above their target ranges during early 1984, the Committee voted to retain their current 1984 growth ranges. The Committee indicated, however, that, given developments in the first half of the year, M3 and total debt might increase at rates somewhat above the limits of their 1984 ranges.

${ }_{11 R e c o r d}$ (April 1984), p. 339.

t2lbid., p. 338
The Committee discussed tentative ranges for 1985 at this meeting and, for M3 and total debt, the 1984 growth ranges were reaffirmed. For $\mathrm{M} 1$ and $\mathrm{M} 2$, how ever, the tentative 1985 ranges were set at rates below those for 1984: the tentative range for $M 2$ was set at 6 to 8.5 percent and, for $\mathrm{M} 1$, a range of 4 to 7 percent was agreed upon.

An important decision in this midyear review was establishing a primary target range for $M 1$ rather than a monitoring range. Incoming evidence suggested that M1 velocity was retuming to a pattern consistent with previous cycles. For instance from $_{r}$ /1983 to II/1984, M1 velocity increased at a 3.3 percent rate and, during the first half of 1984, M1 velocity advanced at a 5.6 percent rate. Thus, with the evidence suggesting that the M1-GNP relationship had returned to a more "normal" pattern, it was agreed that Mi once again would be used as an important tool in the implementation of monetary policy.

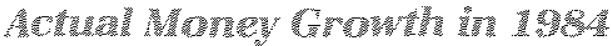

The growth of M1 during 1984, as in 1983, was within the Committee's long-run target range. As shown in table 2, M1 growth was near the lower end of the Committee's 4-8 percent IV/1983-IV/1984 target range. The growth rate for $\mathrm{M} 2$ in 1984 fell in the center of the Committee's annual target: for the period from IV/1983 to $\mathrm{W} / 1984, \mathrm{M} 2$ increased at a 7.7 percent rate. In confrast to $\mathrm{M} 1$ and $\mathrm{M} 2$ growth, the growth of M3 exceeded its target growth. The $\mathrm{T} / 1983$ to $\mathrm{W} / 1984$ growth rate for $\mathrm{M3}$ - 10.5 percent - was 1.5 percent age points greater than the upper bound of the Committee's desired 6 to 9 percent target growth range.

\section{Summatrats}

Two themes clearly are evident in the long-run pol icy decisions of the Federal Open Market Committee. One, the financial innovations of late 1982 and early 1983 influenced the Committee's willingness to establish growth ranges for M1 and, to some extent, M2. The rebasing of each measure's growth targets attests to the fact that the effects of the innovations were viewed as temporary distortions.

While the perception that M2 was temporarily distorted can be found in Committee discussions, the majority opinion was that $\mathrm{M}$ would not prove as dependable an intermediate target as M2. Stemming from the fact that savings-type deposits had recently become a larger proportion of $\mathrm{M} 1$, the Committee continued only to "monitof" its behavior until July 1984. As more data became available through 1984, however, the recognition that $\mathrm{M} 1$ 's behavior was returning to a 
more normal relationship with GNP induced the Committee to assign $\mathrm{M} 1$ a formal target range.

The Committee's setting of long-run growth objectives in 1983 and 1984 secondly reveals its concern over the durability and strength of the recovery. This concern does not seem to have stemmed from monetary policy effects as much as non-monetary factors, which some viewed as a threat to the expansion. Thus, the long-run objectives aimed at promoting the recovery and, at the same time, restraining the probable inflationary impacts of rapid money growth.

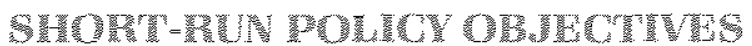

To examine more closely the impact of the changing financial environment and the conflicting information from the real economy, the following discussion presents an outline of the Committee's shortmrun decisions during 1983-84.

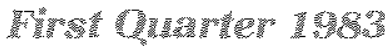

The uncertainties stemming from the effect of the newly introduced MMDA and Super NOW deposits on the monetary aggregates is revealed in the fact that no short-term ranges were established at the February 1983 meeting (see table 3). At the March 28-29 meeting, the data indicated that, although $\mathrm{M} 2$ had increased at an exceptional pace in February due to a continuing influx of non-M2 funds into MMDA accounts, the flow had decreased sharply in March. M1 also had expanded sharply since January. Because the policy importance of $\mathrm{M} 1$ had been lessened since the October 1982 meeting, however, the Committee focused on the behavior of the broader aggregates.

In light of the monetary data, the Committee agreed that it would establish an environment consistent with a slowing in M2 and M3 growth during the March-June period to rates of about 9 and 8 percent, respectively. Consistent with this was a growth range of about 6 to 7 percent for M1, although the growth of M1 was only monitored. It was noted, however, that should predicted behavior of the monetary measures or economic conditions change appreciably, policy prescriptions may be altered during the intermeeting period.

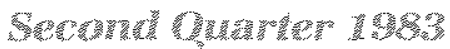

As the year progressed, the growth of real GNP came in faster than had been forecasted. Preliminary data

\footnotetext{
13Synopses of the individual meetings are presented in the supplement to this paper.
}

reviewed at the May 24 meeting showed real GNP rising at about a 2.5 percent rate during $\mathbf{~} / \mathbf{1 9 8 3}$. More timely data indicated a strengthening in the economy: industrial production increased 2.1 percent in April the largest one-month rise since 1975 - and unemployment showed some downward movement. The pace of inflation also continued to be moderate.

The monetary data for the period since the March meeting supported the Committee's expectation that M2 growth would subside once the flow of funds into the MMDA accounts slowed. Indeed, M2 increased at only a 3 percent rate in April after growing at an 11 percent rate in March. Preliminary data for May, how" ever, suggested that M2 growth had picked up again, indicating that over the March-June period it might run only slightly below the 9 percent target rate established in March. As shown in table 5 , the actual growth rate of $\mathrm{M} 2$ during this period was 9 percent.

Although the policy importance of M1 had been reduced, its above-target growth during the first quarter of 1983 concerned some members of the Committee. That concern, together with continued signs of an expanding economy, were factors in the decision to follow a course of slightly reducing reserve availability over the near term, even though $\mathrm{M} 2$ appeared to be running only slightly below the 9 percent target growth rate:

Other Committee members ... felt that at least limited tightening of reserve conditions was desirable in light of the very rapid growth in M1 against the background of accumulating evidence that the economic recovery was accelerating. ${ }^{14}$

Although several members dissented, this policy was reaffirmed in a telephone conference on June 23. The evidence of a continued strengthening in economic activity was mounting, and the growth of $\mathrm{M} 1$. remained relatively rapid. Consistent with these developments, it was agreed that the appropriate action would be a modest increase in reserve restraint, even though the growth rates of M2 and M3 remained near their short-term targets

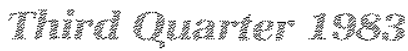

As shown in table 3, the Committee at its July 12-13 meeting established target growth rates for M2 and M3 at about 8.5 percent and about 8 percent, respectively, for the period from June to September. The M1 monitoring rate for this period was set at around 7 percent. At this meeting and again in August when the June-

:Record (August 1983), p. 629. 


\section{Table 3}

\section{FOMC Short-Run Operating Specifications}

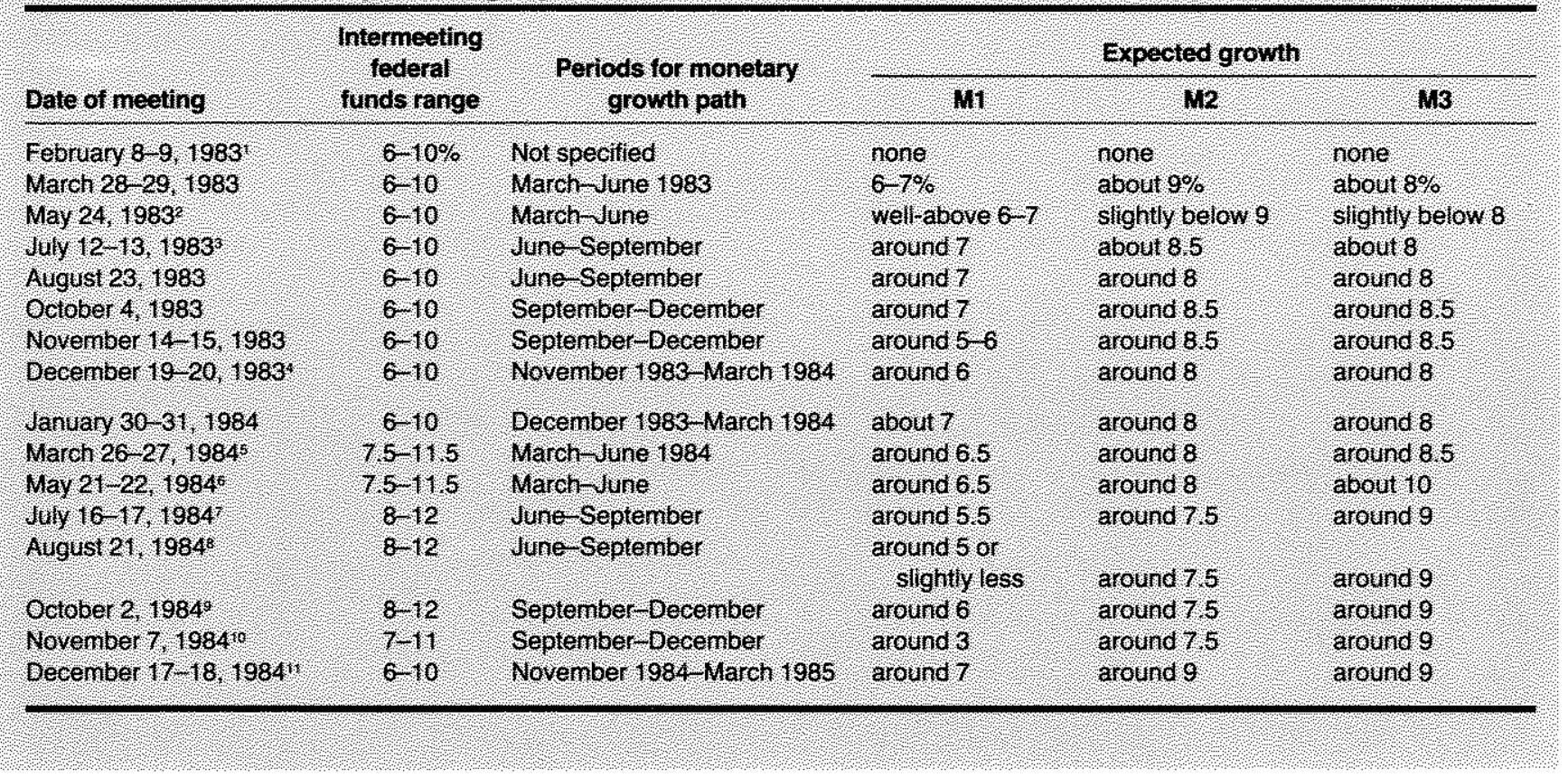

September growth targets established in July remained unchanged, the course and prospects of the economic recovery were discussed at length. The Commerce Department's preliminary estimate of a 6.5 percent growth in real GNP during the second quarter was revised substantially upward to about 9.3 percent. Moreover, incoming data suggested that the economy was continuing to expand quite rapidly in the third quarter. ${ }^{15}$

Some Committee members expressed their concern during these mid-1983 meetings that the economy might "overheat." Two factors stand out in this respect: first, the possible impacts of recently rising interest rates on interest-sensitive sectors of the economy, such as housing; second, the growing belief that large federal deficits and their effects on domestic interest rates could, if left unchecked, "intensify credit market pressures and divert financial and real resources from needed private investment in plant and equipment and housing." As Chairman Volcker stated, "Left unattended the budget deficit] remains

\footnotetext{
${ }^{15}$ For example, the index of industrial production increased 1.8 percent in July; non-farm payroll employment increased in July; production of business equipment continued its early 1983 growth; and inflation, measured by both the producer price and the consumer price indexes, continued to be moderate.
}

${ }^{16}$ Record (October 1983), p. 789. the most single important hazard to the sustained and balanced recovery we want." ${ }^{17}$

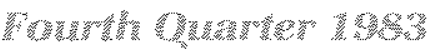

The notion that the budget deficit would adversely affect the economic recovery through its effect on interest rates was stated often during the final meetings of 1983. For example, at the meeting held on December 19-20, the retarding effects of deficit-induced high interest rates again were discussed:

Some emphasized the vilnerability of the economy to a substantial rise in interest rates, should one occur, from levels that were already high in real terms. In this connection, members referred to the desirability of promptaction to reduce the federal deficit, whose size, both current and prospective, was a major factor maintaining upward pressure on interest rates. ${ }^{18}$

The continued rapid expansion of the economy also brought forth concerns about future inflation. Although some Committee members thought that the available evidence from commodity and other price measures did not indicate an acceleration of inflation, others were less optimistic. "The factors cited as harbingers of rising prices included underlying wage pressures, a projected decline in productivity and the

\footnotetext{
"Volcker (1983), p. 603.

rRecord (February 1984), p. 117.
} 


\section{Table 3 (continued) Footnotes - Dissents to FoMC Actions}

Mr Ford dissented from this action because he believed that policy should be directed nore firnly toward gradually reducing monetary

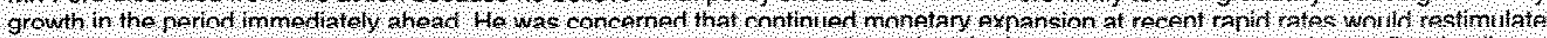
inflation and threaten the sustainablity of the economic recovery, especially against the backdrop of a very expansionary fiscal pollcy.

3Messrs, Solomon, Guftey. Morris, Rice, and Mrs. Teeters dissented from this action because they wanted open market operations to continue being directed toward maintaining approximately the degree of reserve restraint approved at the previous meeting in the view of these members, a firming of resorve conditions was not warranted by the performance of the monetary agoregates of by the ourrent econonic situation N2 and M3 were expanding more slowly in the second quarter than the Committee had anicipated at is previous meeting and for the year to date these broader aggregates, along with total domestic nontinancial credit, were growing at rates that were within the Committee's 1983 ranges. MT had been expanding at a pace markedly in excess of the committee's expectations in recent weeks and for the year to date, but this aggregate was not viewed as a sufficiently reliable guide for policy, at least for the present, since its performance was substantially distorted by various developments and it was not predictably related to nominal GNH.

Under current economic and financial circumstances, the implementation of firmer reserve conditions would also incur an undue risk of an exaggerated reaction in domestic and international financial markets. Substantially bigher domestic interest rates would have darnaging consequences for nterest-sensitive industries and could limit the recovery in economic aclivity. These members agreed that curront interest rate lovels appoared to bo more consistent with continuing oconomic expaneion in the months immodiately ahead, but Mrs. Teeters believed that lower interest rates might well be needed later to sustain the recovery.

These members also referred to the potentially disruptive international impact of rising US interest rates. Messrs. Solonon, Guffey, and Morris in particular believed that the already strong dollar in foreign exchange markets, the tenuous situation of some of the developing countries the still fragile economic recovery in other industrial countries, and the continuing weak outlook for US exports counseled against an ncrease in reserve restraint.

Mis. Teeters dissented rrom this action because she preferred to direct open markel operations toward maintaining the existing degree of reserve restraint. In her view the additional upward pressure on interest rates from further restraint on reserve positions was unnecessary and would retard activity in interest-sensitive sectors of the economy and threaten the sustainability of the recovery.

Mr. Wallich dissented from this action because he favored a directive caling for somewhat greater reserve restraint in his judgment. such a policy course would contribute to better control of the monetany aggregates and, given he strong momentum of the economy, would be more likely to prove consistenl with the Committee's longer run objectives of fostering sustained economic recovery while curbing inilation.

Mr. Martin dissented trom this action because of his concern that any tightening of reserve conditions and the associated increase in interest rates would present a threat to the sustainability of the economic expansion needed business investment would be more expensive, international debt servicing more burdensome, and interest-sensitive housing more vulnerable.

5 Messis. Gramley and Walich dissented from this action because they preferred a directive calling for a somewhat greater degree of reserve restraint and slightly lower objectives for monetary growth in the second quarter in theit view the strength of the economic expansion warranted more restraint now in order to help avert more serious inflation and financial pressures later

Mr Martin dissented because he was concerned that implementation of the Conmittee's policy was likely to lead to more restraint than would be desirable in light of the vuhnerability of key sectors of the economy to rising interest rates, Thrift institutions, housing, agriculture, and also problems associated with less developed country debt were examples that he cited in his view, slightly higher objectives for monetary growth needed to be established tor the second quarter

Mir. Boykin dissented because he believed a directive calling for somewhat greater reserve restraint and marginally lower monetary growth would improve the prospects for curbing intlation and achieving sustainable expansion without incurring a material risk of unsetihy fliancid markets.

Mi. Martin dissented from this action because he wanted to give more weight to the possible need for some easing of reserve conditions in light of the vulnerability of key sectors of the economy and of financial markets to high interest rates He also believed that somewhat higher objectives for monetary growth should be established for the third quarter

sMr. Wallich dissented from this action because he preferred a directive calling for a somewhat greater degree of reserve restraint and marginally lower monetan growth in the third quarter. in his view such a directive was more likely to help avert more serious inflation and financial pressures later:

Messis Martin Rice, and Ms Seger dissented from this action becalsse they preterred a directive calling for a snme what lesser degree of reserve restraint and marginally faster monetary growth in the fourth quarter in their view some additional easing of reserve positions would be appropriate given the reduction in monetary growth over the third quarter and indications of further slowing in the rate of economic expansion Somewhat lesser restraint would not incur a significant risk of stimulating inflation and would also be desirable in light of current conditions in domestic and international financial markets. Mr. Martin in particular expressed concern about strains now being experienced by some tinancial institutions.

10Mt Gramley dissented from this action because he preferred a directive that called for maintaining approximately the existing degree of reserve restraint Despite the pause in the current expansion, underlying forces in the economy, together with the decline in interest rates that had already occurred, were likely to produce a resumption of economic expansion in the reasonably near future. in those circumstances, he was concerned that further easing of reserve positions might lead to a significant decline in interest rates trat woulo subsequently have to be reversed as economic activity and money growth picked up again.

$1 \mathrm{Mr}$. Solomon dissented trom this action because, although he thought some further easing would be appropkiate over the conving period, he believed such action strould be relatively gradual in particular, he was concerned that the provision of resenves sought by the Committee risked an excessive decline in short-term rates and an overreaction in the financial markets. He therefore preferred a more cautious probing towards easier reserve conditions

Mr Gramley dissented because he could not accept a directive that called for further easing of reserve conditions. In his view the underying strength of the economy together with the ongoing effects of earlier declines in interest rates provided the basis for a lkely rebound in oconomic growth during $1085 \mathrm{Hc}$ also beliovod that the Committoo noodod to take grcater account of tho broador monstary aggregates whose expansion appeared to be exceeding the Committee's expectations by a substantial margin in the fourth quarter Under current circumstances he was concerned that significant further easing of reserve conditions would loster addlional declines in interest rates that would have to be reversed later as economic growth picked up again. 


\section{Table 4}

\section{Comparison of Actual and Desired Money Growth: M1}

\begin{tabular}{|c|c|c|c|}
\hline Period & $\begin{array}{l}\text { Desired } \\
\text { growthrate }\end{array}$ & Actual & $y+r o t^{2}$ \\
\hline March June 1989 & $6-7 \%$ & $12,1 \%$ & $56 \%$ \\
\hline June September & around? & 4.5 & -2.5 \\
\hline September December? & around? & 04 & -3.9 \\
\hline November 1983 - March 1984 & around 6 & 72 & 1,2 \\
\hline Decenber 1983 - Narch 1984 & aboul 7 & 78 & 0.8 \\
\hline March unne & around 6.5 & 8.5 & 20 \\
\hline June Seplentuer & around 55 & 21 & 3.4 \\
\hline September December & around 6 & 4.0 & 20 \\
\hline
\end{tabular}

Aclual based on first announced nonthly data.

terror is actual less desired. Where desired growth rate is a range, the nidpont is used.

The September December desited growth rate was revised to around 6 - 6 percent at the November 1983 meeting.

The dine seplember desired growth rate was revised to around 5 percent ail he August 1984 meeting.

possible fall in the foreign exchange value of the dollar.

These concerns are reflected, to a varying degree, in the Committee's directives during these final meetings of 1983. At the October 4 meeting, $\mathrm{M} 2$ appeared to be increasing at a rate well below the desired JuneSeptember pace of 8 percent. As shown in table 5, actual M2 growth for the June-September period was about 6 percent. Although it continued only to be monitored, M1 increased at about a 3 percent rate in August and continued its slow growth into September. In fact, actual M1 growth was 2.5 percentage points below the Committee's desired June-September growth rate of around 7 percent (see table 4).

In contrast to this sluggish end-of-summer growth, the data reviewed at the November and December meetings showed that $\mathrm{M} 2$ was increasing at a pace near the 8.5 percent growth rate established for the September-December period (see table 3 ). The growth of M1, however, was slow in October, increasing at only about a 1.5 percent rate. This slow growth continued through November, then showed a substantial increase in early December. As shown in table 4, M1 increased at a 3.1 percent rate from September to December, well below the Committee's monitoring rate of around 7 percent. Thus, although M1 appeared to be increasing at a slow pace, the strength of the recovery and the renewed growth in the M2 and M3 measures cautioned against an easing policy stance during the final months of 1983 .

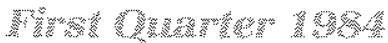

The economic data reviewed at the meeting held on
January 30-31, 1984, suggested that the expansion was slowing. Staff forecasts also suggested that real GNP would grow moderately in 1984. At the same time, most Committee members felt that there would be increased upward pressure on prices in 1984, due to increased cost pressures as the economy experienced a rise in its capacity utilization, decreased unemployment and the possibility of "special circumstances," such as an adverse harvest or a substantial decline in the exchange value of the dollar. With M2 and M3 increasing at moderate rates during December and January, and M1 growth accelerating in January (based on unrevised data), the Committee agreed to a policy action consistent with a growth rate of M2 and M3 of about 8 percent and an M1 growth rate of about 7 percent for the period from December 1983 to March $1984 . .^{19}$

${ }^{19}$ Revised money growth data for 1983 became available after the January meeting. These revisions, based on changes in the 1983 seasonal factors and benchmark adjustments, had significant effects on the growth of the monetary aggregates, especially in the short run. For example, based on original data, $M 1$ increased at rates of 1.9 percent, 0.9 percent and 6.5 percent in October, November and December 1983, respectively. The revisions suggested a much stronger advance: October's growth rate was revised upward to a 6.2 percent rate, November was increased to a 3.2 percent rate and the December figure was revised downward to a 5.3 percent rate. Thus, the growth of M1 in IV/1983 jumped from a 2.1 percent rate to a revised rate of 4.8 percent rate.

The revisions to $M 2$ and $M 3$ data also increased their growth rates for IV/1983. On average, M2's growth rate for October, November and December was increased 1.8 percentage points. Revised M3 growth in November and December was 14 . 1 percent and 8.8 percent, respectively, representing a 2.2 percentage-point increase in the growth rate for each month over the preliminary data. 


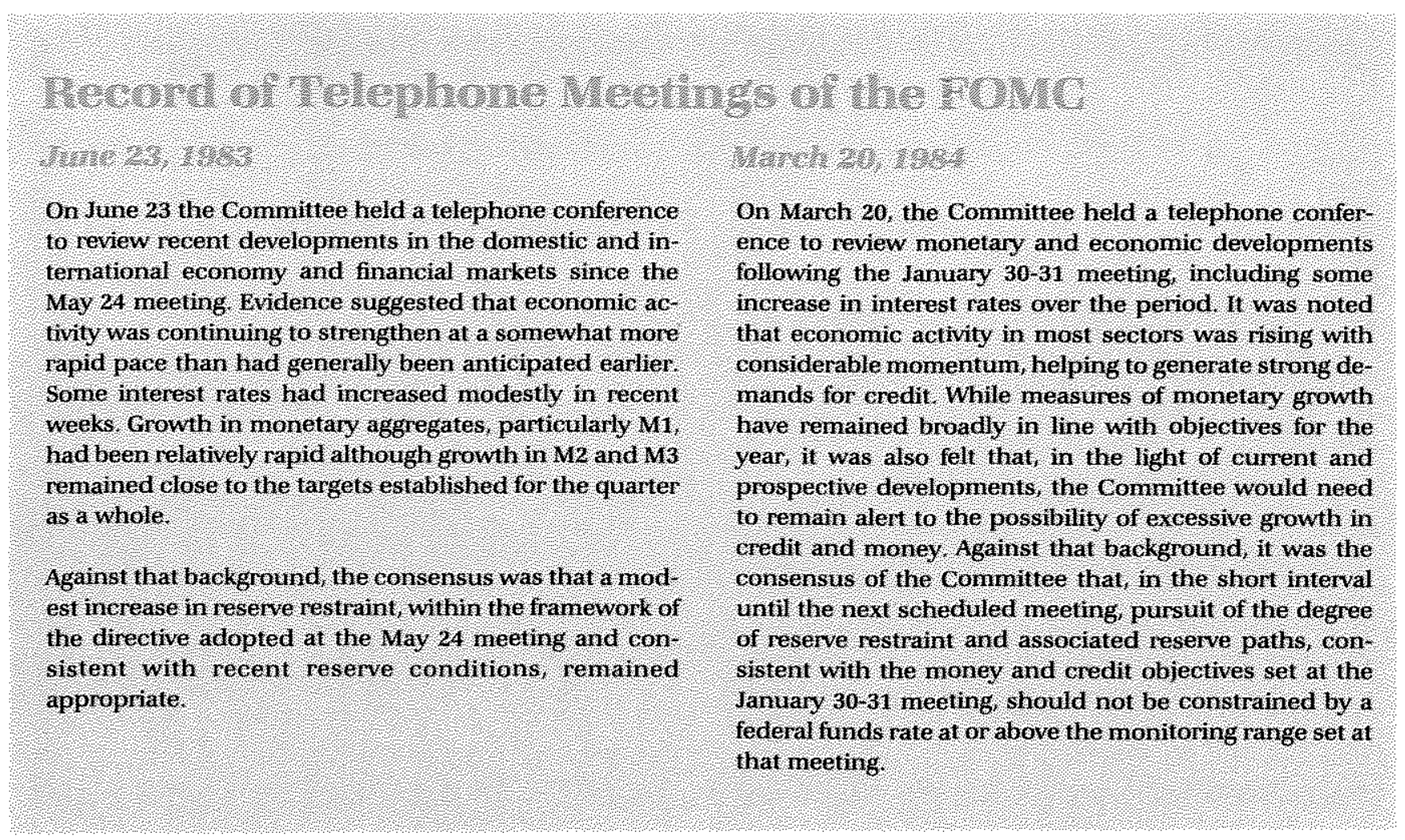

Several changes in the monetary, economic and financial environment had transpired by the March 26-27 meeting. Based on data through mid-March, M1's first quarter growth rate was estimated to be about 7.3 percent, slightly above the short-run objective set in January (see table 3 ). M3 also was showing some first quarter strength, rising at an estimated $\mathbf{8 . 5}$ percent rate. Both of these growth rates already placed the two aggregates near the upper boundaries of their 1984 annual objectives. In contrast, M2 appeared to be increasing at a rate that placed it near the lower boundary of the 6 to 9 percent annual growth rate objective.

The data available at the March meeting suggested that real GNP growth was accelerating during $1 / 1984$, in contrast with earlier projections. In actuality, real GNP increased at a 10.1 percent rate in L/1984, up from the 5.9 percent growth rate for $\mathrm{IV} / 1983^{20}$ Moreover, monthly data available to the Committee at the March meeting indicated falling unemployment and moderate price increases.

Market interest rates generally increased 75 to 100 basis points between the January and March meetings. Concern about these rising rates is reflected by the telephone conference held on March 20, about a

20Based on revised data. week before the regularly scheduled March meeting. During that discussion, the consensus was to pursue the prevailing degree of reserve restraint, even if the federal funds rate was persistently above the upper boundary of 10 percent.

In light of these data, the FOMC decided at the March meeting to maintain enough pressure on bank reserve positions to be consistent with March-to-June growth rate objectives of around 6.5 percent for M1, 8 percent for $\mathrm{M} 2$ and 8.5 percent for $\mathrm{M} 3^{21}$

An increase in credit demands during early 1984 , along with the relative restraint in money growth, necessitated an increase in the intermeeting range for the federal funds rate to 7.5 to 11.5 percent, the first such increase in over a year. In making this decision, Committee members recognized that, not only was there upward pressure on the federal funds rate, but

\footnotetext{
2Three members dissented from this action. Governors Gramley and Wallich dissented in favor of a directive urging more reserve restraint and lower objectives for money growth in the near term. Their view was predicated on the idea that more restraint, given the already robust recovery, would reduce the necessity of significant restraint in the future should greater inflationary and financial market pressures develop.
}

Governor Martin also dissented, based on the belief that currently rising interest rates would adversely affect certain sectors of the economy, such as housing, agriculture and thrift institutions. 


\section{Table 5}

\section{Comparison of Actual and Desired Money Growth: M2}

\begin{tabular}{|c|c|c|c|}
\hline Pertod & $\begin{array}{l}\text { Desired } \\
\text { growhthete }\end{array}$ & Actual & Error \\
\hline Decenoer 1982 March 1983 & around $95 \%$ & $236 \%$ & $141 \%$ \\
\hline March une & about 9 & 90 & 0.0 \\
\hline June-september & $260 u t 85$ & 61 & 24 \\
\hline September December & around 8.5 & 75 & 10 \\
\hline November 1983 -March 1984 & around 8 & 65 & 15 \\
\hline December 1983 - March 1984 & around 8 & 60 & 20 \\
\hline March lune & around 8 & 79 & -01 \\
\hline June-seplember & around 75 & 59 & 16 \\
\hline September December & around 75 & 127 & 52 \\
\hline
\end{tabular}

Actual based on tirst announced mothiny data.

Eeror is actualless desited

The June September desired growth rate was revised to around B percent at the August 1983 meeting

the funds rate would likely fictuate more because of changing market expectations and the newly introduced two-week reserve period. ${ }^{2 x}$

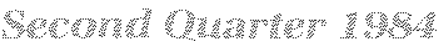

During the period between the March and the May $21-22$ meetings, interest rates continued to rise. In response to these rising rates, the Federal Reserve Board increased the discount rate from 8.5 percent to 9 percent effective Apri 9,1984 . This increase, the first since late 1982 , came in response to lavger spreads between short-term market interest rates and the discount rate. As noted in the minutes of the May 21-22 meeting;

The increases in market rates apparenty reflected continuing strong eredit demands as economic acti" ity expanded, the absence of rapid progress in reducing the federal deficit, and related concerns about future inflationary pressures and a possible need lor a more restricive provision of reserwes. ${ }^{23}$

Along with rising interest rates, the data avalable at the May meeting indicated that the real economy continued to expand at a relatively strong pace. Moreover, the growth of $\mathrm{M} 2$ and $\mathrm{M} 3$ in April was consistent with the short-run objective set at the March meeting. M1, however, showed essentialy no change in its level beween March and Aprl. Sarly May data, on the other hand, suggested that M1 growth was strengthening considerably.

\footnotetext{
2For a discussion of the effects of the contemporaneous reserve tequirements, see Thonton (1983b).

23Record (August 1984), p. 647 .
}

In response to the conflicting signals from the monetary measures, the economy and the financial markets, the Committee at its May meding reaffimed the March-to-June growth rates for M1 and M2 established at the March 26-27 meeting (see table 3). The range for M3 growh was increased to about 10 percent, up from the 8.5 percent rate previously set.

\section{W}

Interest rates continued to increase through the summer. By the July 16-17 meeting, the federal funds rate was about 75 basis points above its level at the May meeting. Interest rates on bank CDs also were 50 to 75 basis points higher. ${ }^{27}$ In contrast, rates on shorttem Treasury bills were little changed. Moreover, relanve to the Committee's desired money growth rates for the March-June period, M1 was above its range (table 4), while $M 2$ and $M 3$ were about in line with expectations for the three-month period (table 5 ).

The Committee faced an economic horizon clouded by a variev of signals. It consequently agreed on pol. icy actions consistent with getting the growth of the monetary aggregates back to the desired annual range. To do this, the June-September growth rate objectives for M1, M2 and M3 each were revised downward from. the March-June path (see table 3 ). The Committee also favored a furher increase in the intemeeting range of the federal funds rate to 8 to 12 percent.

\footnotetext{
${ }^{24}$ Although $C D$ rates were higher, there was concern that the recent problems with Continental Illinois may have imparted a large risk premium in bank CDs.
} 
The rise in short-term interest rates continued through the August 21 meeting. In response, some Committee members noted that a "lessening in the degree of reserve restraint would appropriately tend to offset the unusual pressures that had developed in the federal funds market during June and July." ${ }^{2}$

This lessening in reserve restraint also was noted with regard to the recent behavior of the monetary aggregates. M1, for example, had declined at about a 1 percent rate in July, after increasing at about a 12 percent rate in June. Early August data suggested that M1 growth had recovered somewhat and that M2 growth was increasing at a relatively slow pace. In light of the available data and the relative uncertainty prevailing in financial markets, a June-September M1 growth of 5 percent or slightly less, down 0.5 percentage points from the three-month rate established at the preceding meeting, was agreed upon. The rates for M2 and M3 were not changed (see table 3 ).

\section{TORg}

Signs of an appreciable slowing in the pace of economic activity appeared by the October 2 meeting. The available data indicated that real GNP was still expanding, but that its rate of growth had declined substantially since the first half of 1984 . Final sales growth also was off from rates established earlier, and the rate of inventory accumulation had picked up sharply. Consumer spending was down during the late summer months, and housing starts fell sharply in August.

In addition, the monetary data pointed to an unexpected shortfall in money growth for IIU/1984. The available evidence showed $\mathrm{M} 1$ decreasing at a 1.1 perm cent rate in July, a modest 2 percent rate of growth in August and a moderate acceleration in September. The broader measures, $\mathrm{M} 2$ and $\mathrm{M}_{3}$, also increased at relatively sluggish rates during July and August, In September, each measure showed some rebound in growth ${ }^{36}$

At the October 2 meeting, a policy of increased reserve availability, followed during the August-October intermeeting period, was continued. As shown in table 3 , this policy was expected to be associated with a September-December growth rate for M1 of around 6 percent, up from the sluggish growth for the third

\footnotetext{
${ }^{25}$ Record (November 1984), p. 825 .

26The growth raies of 12 for Jusy, August and September coriginal values) were 5.3 percent, 4.9 percent and 7.9 percent, respectively. The relevant growth rates for $M 3$ are 5.0 percent, 8.0 percent and 11.2 percent.
}

quarter. The growth rates for $\mathrm{M} 2$ and $\mathrm{M3}$ also were expected to be slightly above actual third-quarter rates.

Although this increase of reserve availability was expected to produce faster fourth-quarter monetary growth, the data available at the November 7 meeting continued to indicate that $\mathrm{M} 1$ and $\mathrm{M} 2$ were running below fourth-quarter expectations. Although data for M1 growth showed a shapp increase in September, available October data suggested that M1 growth would be negative.?

The persistent sluggish growth of M1 again generated opposing viewpoints among Committee membens about the reliability of $\mathrm{M} 1$ as an intermediate target for policy. This is revealed in the following report of the discussion:

Dufing the Committee's discussion of policy implementation for the weeks immediately ahead, a number of members expressed concem about the persisting weakness in M1, especially in the context of the con" current "pause" or "lull' in the economic expansion, and they saw a need for some easing of reserve conditions to encourage a resumption in $\mathrm{M} 1$ growth. Other members, while not necessarily disagreeing, nonetheless noted that the recent expansion of $\mathrm{M} 2$ had been much closer to the Committee's expectations and that growth in M3 had been somewhat faster. A few members cautioned against putting too much emphasis on M1 in light of its typically volatile behavior, the difficul ties of achieving accurate seasonal adjustments, and the often unpredictable relationship of M1 to aggregate measures of economic performance. ${ }^{2 *}$

In setting policy for the intermeeting period, the Committee voted for policy actions consistent with a growth rate for $\mathrm{M} 2$ of around 7.5 percent and for $\mathrm{M} 3$ of around 9 percent for the September-December pe* riod. In each case, the expected growth was the same as that indicated at the October meeting. In contrast, M1 was expected to increase at only around a 3 percent rate during the fourth quarter, or about half the monitoring growth rate set at the October meeting. In addition, the intermeeting federal funds rate range was dropped to 7 to 11 percent, down from the 8 to 12 percent range used since the July 16-17 meeting. This reduction reflects the fact that interest rates fell sub. stantially during the October-November intermeeting period.

\footnotetext{
${ }^{27}$ The sharp increase in September's growth rate over August $(4.9$ percent vs. 2.0 percent) feflects the effect of abovt a $\$ 7$ billion increase during the week of September 10 . This increase, reflecting the so-called Social Security effect, was temporary: during the next few weeks, reporied changes in $M 1$ were negative. in fact, the growth rate for October was -7.0 percent.

${ }^{28}$ Record (February 1985), p. 95.
} 
Between the November and December meetings, open market operations were directed towand an easing of reserve pressures in the banking system. This policy course was taken for several reasons: "lagging growth in the narrow money supply, generally slug. gish expansion in the economy, subdued inflation, and continued strength of the dollar in foreign exchange markets."

The desire to increase reserve availability during this period stems partly from the observation that, even with a strong growth of M1 in November (about 8.5 percent), M1 growth was low since summer and would probably come in somewhere in the lower half of the Committee's 1984 range. Indeed, the discussion of policy actions at the December meeting focuses on the behavior of M1 more so than during previous meetings. This is clear from the fact that, even though the policy for the intermeeting period called for easing reserve positions, M2 and M3 had shown extremely strong advances in November $(15$ percent and 16 percent, respectively).

At the December meeting, some members favored "some further easing of reserve conditions to encourage satisfactory growth in M1 and to improve the prospects for economic expansion in 1985." ${ }^{30}$ Also,

because of the currently estimated shortfall in M1 growth in the fourth quarter compared with the members' expectations at the beginning of the quarter, the Committee decided that somewhat more rapid growth of $\mathrm{M} 1$ would be acceptable for the period ahead, particularly if the faster growth occurred in the context of sluggish expansion in economic activity and continued strength of the dollar in foreign exchange markets. ${ }^{31}$

Thus, in the final meetings of 1984, concern about various factors that might slow the expansion continued to play a major role in policy discussion. Staff forecasts anticipated a moderate expansion in 1985. Even so, considerable attention was paid to the "potential complications associated with massive and sustained federal deficits and very large imbalances in the nation's foreign trade. "32

Because of uncertainty about the sustainability of the expansion, the Committee established the November 1984-towarch 1985 short-run growth ranges for M1 and M2 at rates slightly above those for the fourth quarter. The range for $\mathrm{M} 1$ was set at around 7 percent; for $\mathrm{M} 2$, it was set at around 9 percent. Combined with a lowering of the intermeeting federal funds range to 6 to 10 percent, this decision reflected the consensus that somewhat faster money growth was desirable.

\section{CONDE}

The impact of financial deregulation on the measurement and interpretation of the monetary aggregates, along with concern about the strength of the economic recovery, were major factors influencing the setting of monetary policy in 1983 and 1984. The potential effect of two new accounts - money makket deposit accounts in December 1983 and Super NOW accounts in January 198 - on the growth of $\mathrm{MI}$ and M2 influenced the Committee to continue its policy of giving little weight to $\mathrm{M} 1$ behavior and, with regard to M2, to alter the base period for the 1983 annual target to a February March average. Indeed, the uncertainty about M1 growth and the coincident behavior of its income velocity perpetuated the Committee's position begun in late 1982 of basing policy primarily on behavior of the broader aggregates throughout 1983 and the first half of 1984 .

Uncertainty about the economic recovery also pervaded Committee discussions during the past two years. This concern arose not only from the changing behavior of the money-income linkage, but also from the massive increases in the federal deficit, variable interest rates and the sustained strength of the dollar in foreign exchange markets. In large part, however, these fears did not materialize in a faltering economic expansion.

Changes in the financial and economic environment will continue to influence monetary policy makers' decisions. Although changes in financial regulations influenced the use of monetary aggregates, especially $\mathrm{M} 1$, during the past two years, recent evidence and Committee discussions suggest that M1 is once again receiving an important place in policy. The important policy problem confronting the Committee once again is how to maintain a norinflationary growth of the monetary aggregates in the context of a dynamic economy.

\footnotetext{
ribid., p. 232

39lbid., p. 234.

${ }^{3}$ lbid., p. 235.

ṡlbid., p. 233
}

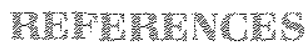

Axilrod, Stephen H. "Isstues in Monetary Targeting and Velocity," in Monetary Targeting and Velocity (Federal Reserve Bank of San Francisco, 1983). 
Davidson, Lawrence S., and R. W. Hafer. "Some Evidence on Selecting an Intermediate Target for Monetary Policy, Southern Economic Joumal (October 1983), pp. 406-21.

Friedman, Benjamin M. "The Relative Stabllty of Money and Credit 'Velocities' in the United States: Evidence and Some Speculations," Working Paper No. 645 (National Bureat of Economic Research, 1981).

"Monetary Policy with a Credit Aggregate Target," in Karl Brunnef and Allan H. Meltzer, eds. Money, Monetary Policy, and Financial Institutions, Carnegie-Rochester Conference Series on Public Policy (Spring 1983a), pp. 117-48.

"The Roies of Money and Credit in Macroeconomic Analysis," in James Tobin, ed., Macroeconomics, Prices, and Quantities: Essays in Memory of Arthur M. Okun (The Brookings Institution, 1983b), pp. 161-89.

Hafer, R. W. "The Money-GNP Link: Assessing Alternative Transaction Measures," this Review (March 1984a), pp. 19-27.

\footnotetext{
"Money, Debt and Economic Activity," this Review (June/July 1984b), pp. 18-25.

"Choosing Between M1 and Debt as an Intermediate Target for Monetary Policy," in Karl Brunner and Alan Melzer, eds., Carnegie-Rochester Conference Series on Public Policy (Spring 1985, forthcoming).

Judd, John P. "The Recent Decline in Velocity: Instability in Money" Demand or Inflation?" Federal Reserve Bank of San Francisco Economic Review (Spring 1983), pp. 12-19.
}

Keran, Michael W. "Velocity and Intlation Expectations: 19221983," Federal Reserve Bank of San Francisco Economic Review (Summer 1984), pp. 40-55.

Kopcke, Fichard W. 'Must the Ideal 'Money Stock' be Controlable?" New England Economic Review (March/April 1983), pp. $10-23$.

Morris, Frank E. "Do the Monetary Aggregates Have a Future as Targets of Federal Reserve Policy?" New England Economic Review (March/April 1982), pp. 5-14.

"Monetarism without Money." New England Economic Review (March/April 1983), pp. 5-9.

Porter, Richard D., and Edward K. Offenbacher. "Empirical Comparisons of Credit and Monetary Aggregates Using Vector Autoregressive Methods," Federal Aeserve Bank of Richmond Economic Review (November/December 1983), pp. 16-29.

Tatom, John A. "Alternative Explanations of the 1982-83 Decline in Velocity," in Monetary Targeting and Velocity (Federal Reserve Bank of San Francisco 1983).

Thornton, Daniel L. "The FOMC in 1982: De-emphasizing M1," this Review (June/July 1983a), pp. 26-35.

"Lagged and Contemporaneous Reserve Accounting: An Alternative View," this Aeview (November 1983b), pp. 26-33.

Volcker, Paul A. "Statement before the Committee on Banking, Finance and Urban Affairs," Federal Reserve Bulletin (August 1983), pp. $601-09$.

\section{Supplement}

\section{FOMC Discussions in 1983 and 1984}

This supplement provides the reader with a chronological account of policy discussions for the meetings held in 1983 and 1984. These selected excerpts are taken from the "Record of Policy Actions." Included in each "Record" are analyses of current economic conditions, staff projections of future economic developments, discussions of existing and possible policy actions and a reporting of the operating instructions issued by the FOMC. The full text of each "Record" appears in issues of the Federal Reserve Bulletin.

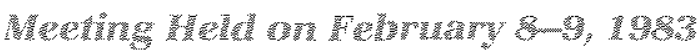

On several occasions following the December meeting, the Committee discussed the extraordinarily rapid growth in MMDAs that had taken place since the accounts had become available in mid-December and the implications of that growth for the behavior and interpretation of the monetary aggregates. At the conclusion of a discussion on January 28,1983 , it was the Committee consensus to maintain the existing degree of reserve restraint for the time being but not to increase that restraint further in response to the reported over-target growth of the broader monetary aggregates because that growth appeared to be primarily related to the massive redistribution of funds under" way.
At this meeting it was reported that MMDAs had grown to more than $\$ 210$ billion by late January, and available evidence suggested that some of the December increase in M2 and much of the surge in January was related to the associated shifts of funds out of non-M2 assets - such as market instruments and large-denomination CDs - into MMDAs.... Growth of M1 remained rapid in January, although the increase was appreciably smaller than the average pace in other recent months. To date, $\mathrm{M} 1$ growth appeared to have been little affected on balance by the introduction of MMDAs in mid-December or of Super NOW accounts in early January,

While the outlook for economic activity and prices was generally viewed as favorable, it remained subject to considerable uncertainty. Some members stressed the potential obstacles to a sustained recovery, including the prospect of continuing large federal deficits in the absence of new legislation, the outlook for weak export markets, real interest rates that were still high by historical standards, and the possibility of further disturbances in international and domestic financial markets. On the other hand, a number of members commented that once under way, the recovery might gather momentum and prove to be markedly more 
vigorous than the staff had projected, with the expansion in 1983 perhaps more in line with the average experience in the first year of previous economic recoveries.

For 1983 the Committee faced the question of whether underlying relationships between monetary and ultimate economic objectives might still be in the process of changing. Past cyclical expansions had typically been accompanied by sharp increases in velocity particularly for the nar. rower measures of money... Members recognized that it could take some time before this newly emerging behavior of M1 in relation to GNP became clear. The broader monetary aggregates, too, were being affected by institutional changes, with M2 especially influenced in 1983 by shifts into its MMDA component from market instruments and large-denomination CDs.

In the course of the Committee's discussion, a consensus emerged in favor of setting target ranges for all three measures of money but to depart from past practice in some respects in light of the complexities and uncertainties that were involved. Most of the Committee members agreed that it would be desirable for the time being to place substantial weight on the broader aggregates, M2 and M3. It was expected that, once the bulk of shifts had taken place, the performance of those aggregates in relation to economic activity might be somewhat more predictable than that of M1 during the year ahead, although major uncertainties affected all of the aggregates.

It was agreed that the behavior of M1 would be monitored and that the degree of emphasis to be placed on that aggregate as the year progressed would depend on evidence about whether the behavior of the velocity of M1 was becoming more predictable and beginning to show its usual cyclical characteristics.

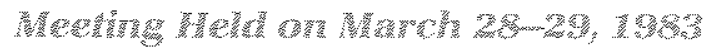

M2 grew at an estimated annual rate of about 24 percent in February, only a little below the exceptional pace in Jartuary, as its growth continued to be greatly affected by shifts of funds from market instruments and other non-M2 sources into the new money market deposit accounts (MMDAs) included in M2. M3 grew at annual rates of about 12 and $13^{1 / 2}$ percent in January and February respectively. However, growth in both of the broader aggregates appeared to have decelerated substantially during March.

Growth in $\mathrm{M} 1$ accelerated to an extraordinary annual rate of about 22 percent in February, and, on the basis of preliminary data, was estimated to have remained rapid in Marun, though probably slowing somewhat from the February rate.

In the Committee's discussion of the economic situation and outlook, the members agreed that a recovery in economic activity appeared to be under way, although several commented that the evidence available thus far was too fragmentary to permit a firm evaluation of the strength of the upturn.

Reference was also made to the retarding impact of rela- tively high real interest rates, and some members expressed the view that an appreciable rise in interest rates, if such a rise were to occur, could greatly inhibit the recovery in interest-sensitive sectors of the economy, such as housing and automobiles, which had tended to lead the recovery thus far.

With respect to M1, most members felt that persistence of its unusually sharp decline in velocity early this year cast doubt on the aggregate as a principal guide for policy at this time; however, a view was also expressed in favor of giving M1 more weight in the formulation of the Committee's policy.

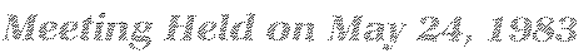

In the course of their discussion, Committee members expressed differing views with regard to the appropriate course for policy in the weeks immediately ahead. The members were narrowly divided between those who fa" vored some increase in reserve restraint over the next few weeks and others who preferred to maintain the degree of reserve restraint contemplated at the March meeting. This divergence reflected varying assessments of the strength and sustainability of the economic recovery; differing views with regard to the interpretation of the monetary aggregates; and different opinions conceming the risks associated with the likely impact of alternative policy courses on domestic interest rates.

A number of members were also concerned that under current circumstances even a modest tightening of reserve conditions might have a disproportionate impact on sentiment in domestic and international financial markets and lead to sizable increases in domestic interest rates.

Other Committee members, however, weighed the risks associated with alternative policy courses differently. They felt that at least limited tightening of reserve conditions was desirable in light of the very rapid growth in $M 1$ against the background of accumulating evidence that the economic recovery was accelerating.

Several members commented that slightly greater restraint on reserves would be desirable at this point to minimize the possible need for more substantial restraint later, reducing the interest rate impact on financial markets over time and helping to sustain the expansion. Reference was made to the favorable effect such a move might have on market perceptions about monetary policy and the outlook for containing inflation, with the consequence that prospects for stable or declining interest rates in long-term debt markets would be enhanced as the recovery proceeded.

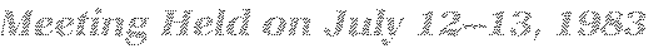

Growth in M2 and M3 accelerated in May and continued relatively strong in June, with both aggregates expanding at an estimated annual rate of about 10 percent.

M1, which had surged to an annual rate of growth of about 26 percent in May, expanded at a rate of around $10^{1 / 2}$ 
percent in June.

The view was expressed that the restraining impact on private credit demands and economic activity of even current relatively high interest rates - which seemed espe. cially high in real terms - could well be underestimated, and a view was expressed that a decline in interest rates from present levels would probably be needed to prolong the recovery during 1984 .

At this meeting the Committee reviewed its target ranges for 1983 and established tentative ranges for 1984 in light of the basic objectives of encouraging sustained economic recovery while fostering continued proggess toward price stability and promoting a sustainable pattern of international transactions. In setting these ranges, the Committee recognized that the relationships among the money and credit aggregates and nominal GNP in the period ahead were subject to considerable uncertainty.

Against this background, a key uncertainty confronting the Committee was whether M1 velocity in the future would exhibit characteristics more in line with earlier postwar experience. Recent evidence seemed to suggest that the decline in $\mathrm{M} 1$ velocity was ending, as might be expected as the lagged upward effect on demand from earlier declines in interest rates wore off and as business and consumer attitudes became more optimistic.

In this view $M 1$ would continue to be given reduced weight in the formulation of monetary policy and primary emphasis would continue to be placed on the broader aggregates. A few members, however, preferred to suspend the targeting of $\mathrm{M} 1$ at this time because they viewed its prospective behavior as too uncertain to permit the establishment of a meaningful mange.

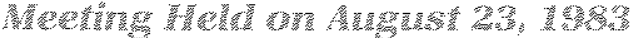

Wirh a little greater restraint on reserve availability relative to demands, the federal funds rate and other short-term interest rates rose about 20 to 40 basis points on balance over the intermeeting period. Atypically, long-term rates rose by more than short-term rates, increasing about 80 basis points. Market participants apparently reacted to indications of further strength in the economy, to concern about possible increases in inflationary pressure later during the economic recovery, and to the heavy borrowing by the U.S. Treasury, particularly in connection with the midAugust financing; as well as to the slightly firmer degree of restraint on bank reserve positions.

Members continued to express concem about the prospects for large federal deficits. Although a stimulative fiscal policy had contributed to the rebound in economic activity, continued large deficits as the recovery proceeded would ternd to intensify credit market pressures and divet finan cial and real resources from needed private investment in plant and equipment and housing. The view was expressed that actions to reduce future deficits, if of sufficient magnitude, could work to ease pressures on interest rates in a period of rising private credit demands.
Tuming to policy for the near term, the Committee considered whether any further adjustment in the degree of restraint on bank reserve conditions would be desirable under current economic and financial circumstances, given the behavior of the monetary and credit aggregates. The members noted that growth in the broader aggregates, on which the Committee had been placing primary emphasis, had slowed substantially... Growth in M1 had modetated somewhat further in July, but it remained above the shortrun, June-to-September path that the Committee had expected would be consistent with its third-quarter objectives for the broader aggregates and also above its longer-run monitoring range. Incoming data suggested, however, that M1 growth would probably continue to decelerate in August.

At the conclusion of the discussion the members agreed that no change needed to be made at this time in the degree of pressure on bank reserves. Accordingly, a consensus was expressed in favor of maintaining about the existing degree of reserve restraint for the period immediately ahead.

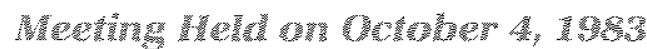

In the latter part of the summer, growth in M2 remained at, or below, its reduced pace in July, and over the June-toSeptember period its growth was estimated to have been well below the annual rate of around 8 percent expected by the Committee. Growth in M3 strengthened somewhat in late summer and in the third quarter that aggregate expanded at a pace close to the expected rate. Meanwhile, expansion in $M 1$ fell to an anmual rate a little below 3 percent in August, and growth remained relatively low in September. By september all three monetary aggregates appeared to be within the longer $r$ run ranges specified by the Committee, with $\mathrm{M} 2$ in the lower portion of its range, M3 in the upper portion of its range, and M1 somewhat above the midpoint of its monitoring range.

In the Committee's discussion of the economic situation, the members were generally optimistic about the prospects for continued recovery in economic activity and containment of inflationary pressures. They agreed that the staff projection of moderate economic growth seemed to be the most likely outcome for the year ahead, and in this connection some members commented that a more moderate rate of economic growth than that experienced recently would be more consistent over time with sustaining the expansion and containing inflation. The view was expressed, however, that the rate of inflation could turn out to be somewhat higher than projected and the rate of expansion somewhat slower .. . the members again expressed a great deal of concern about the prospects for massive federal deficits. It was observed that the Treasury's large borrowing needs were already exerting upward pressure on interest rates, and that greater pressure could be expected if relatively large Treasury credit demands continued and were augmented by growing business demands for a substantial amount of external funds to finance their investments. 


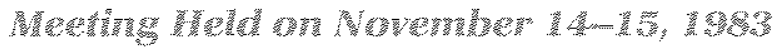

In October, both $\mathrm{M} 2$ and $\mathrm{M} 3$ grew at annual rates close to the $8^{1 / 2}$ percent pace sought by the Committee for the September-to-December period: growth in M2, after slowing substantially over the summer months, accelerated to an estimated annual rate of about 9 percent, while growth in M3 was at an estimated annual rate of about $81 / 4$ percent. On the other hand, expansion in M1, at an annual rate of about $1^{1 / 2}$ percent, remained low. Through October, M2 was at a level in the lower portion of the Committee's range for 1983 and $\mathrm{M} 3$ was in the upper portion of its range. M1 was in the lower portion of the Committee's monitoring range for the second half of the year.

While all the members expected the rate of economic growth to moderate over the year ahead, there were some differences of view with regard to the timing and likely extent of the slowdown. Some members anticipated that the slowdown might be appreciably less than projected by the staff, with unfavorable implications for inflationary pressures and the ultimate sustainability of the expansion.

In the view of some, however, an argument could be made in favor of a small, precautionary step in the direction of firming in light of the continuing strength of the economic expansion and the associated danger of a resurgence of inflationary pressures during the year ahead. While acknowledging the risks of inflation in a rapidly expanding economy combined with large budget deficits and the relatively rapid monetary growth earlier in the year, most members saw sufficient uncertainties in the outlook to counsel against any change in reserve pressures at this time. Some members were also concemed that under the prevailing circumstances even a modest increase in restraint on reserves might have a disproportionate impact on domestic and international financial markets.

One member indicated a preference for giving increased weight to $\mathrm{M} 1$ in the formulation of monetary policy and commented that its slow growth, should it persist, could threaten the sustainability of the economic expansion. Other members commented that the deceleration of M1 growth in recent months had to be evaluated against the background of unusually rapid expansion in the latter part of 1982 and the first half of 1983 .

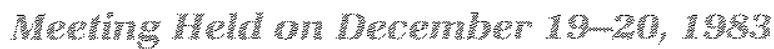

In the view of some Committee members, the expansion in economic activity during $1984 \mathrm{might}$ well exceed the staff projection, given the momentum of the recovery and a stimulative fiscal policy.

Other members were somewhat less sanguine about the prospective strength of the ongoing expansion. Some emphasized the vulnerability of the economy to a substantial rise in interest rates, should one occur, from levels that were already high in real terms. In this connection, members referred to the desirability of prompt action to reduce the federal deficit, whose size, both current and prospec- tive, was a major factor maintaining upward pressure c interest rates.

While nearly all the members could accept a policy maintaining at least the existing degree of reserve restrair some expressed a preference for some slight firming imm diately in light of their assessment of the economic situ tion and concerns about the potential for a reemergence inflationary pressures. Other members preferred to mal no change in the existing degree of restraint for now, pen ing a further evaluation of economic developments ar monetary growth.

A number of members were also influenced by the rel tively sluggish growth of M1 over the course of rece: months, although such growth appeared to be acceleratir in December. Some urged that greater weight be placed $c$ $M 1$ in the formulation and implementation of policy; and the view of one member, reserve conditions should $t$ eased promptly if it became clear that growth in M1 w: remaining sluggish.

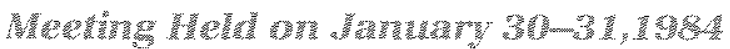

In the Committee's discussion, nearly all the membe indicated that the ranges tentatively established for $19 \varepsilon$ remained acceptable ${ }_{r}$ although some expressed a prefe ence for slightly lower ranges for one or more of th aggregates.

The ranges under consideration for 1984 assumed th: the relationships between the monetary aggregates an nominal GNP - the velocity of money - would be broad consistent with past trends and cyclical patterns followir atypical behaviof in 1982 and early 1983. A tendency fo velocity to rise as 1983 progressed suggested a return th ward earlier velocity pattems, but several Committee men bers believed that more experience was needed before th: trend was confirmed.

In this situation most members agreed that for the tim being substantial weight should continue to be placed o M2 and M3 in policy implementation, while growth in M should be evaluated in light of the performance of th broader aggregates. The view was expressed that emphas: on the broader aggregates appropriately recognized th remaining uncertainties with respect to the relationshi between M1 and economic activity, and it was also observe that the use of a relatively wide range for $\mathrm{M} 1$ tended to wor in the same direction. However, one member urged placin primary emphasis on M1 and also supported a narrowe range for that aggregate, noting that the introduction c contemporaneous reserve accounting provided an oppos tunity to exert closer control over its short-run behavior. number of other members supported giving M1 greate weight, if not primary emphasis, in light of what they viewe as the emergence of a more predictable pattern in its velor ity, at least in relation to that of $\mathrm{M} 2$ and of $\mathrm{M3}$. Still othe members were not prepared to increase the policy role c M1, at least at this time. In the view of these members, th prospective behavior of $\mathrm{M} 1$ velocity remained subject $t$ 
unusual uncertainties, in part because of the institutional changes reflected in the increased role in M1 of NOW (negotiable onder of withdrawal account) and super NOW components, which bear interest and serve both a transactions and a longer-term savings function. These and related changes made it difficult to anticipate the public's demand for cash balances under varying circumstances or the response of depository institutions in altering terms on the newer components of M1.

In the Committee's discussion of policy for the short run, all of the members indicated that they could support a policy directed toward maintaining essentially the existing degree of restraint on reserve positions. Such a policy was thought likely to be associated with short run growth in the monetary aggregates consistent with the Committee's objectives for the year.

In their discussion the members took note of uncertainties associated with the introduction of contemporaneous reserve accounting on February 2 . The members agreed that no substantial changes would be made in open market operating procedures at this time, but they anticipated the passage of some time before depository institutions fully adjusted their reserve management to the new accounting system, In that interval, for instance, depository institutions might want to hold more excess reserves than usual. The members agreed that such developments would need to be accommodated by adjustments to reserve paths.

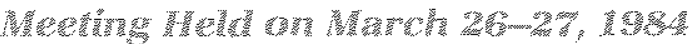

Data avallable through mid-March indicated that since December $\mathrm{M} 1$ and $\mathrm{M} 3 \mathrm{~h}$ had been expanding somewhat more rapidly than anticipated at the January meeting. Tentative estimates suggested that in the first quarter as a whole M1 and $M 3$ grew at annual rates of about $7^{1 / 4}$ percent and $8^{1 / 2}$ percent from the fourth quarter, well up in their longer-run ranges of 4 to 8 percent and 6 to 9 percent respectively established by the Committee for 1984 . Growth in M2 appeared to have been less rapid than previously expected and was estimated to be at a rate in the lower part of the 6 to 9 percent range for 1984 .

Market interest rates moved considerably higher over the intermeeting period, generally rising about $3 / 4$ to 1 percentage point in both short and long-term markets. The increases appeared to be induced by the strength of economic activity and private credit demands, disappointment over the absence of significant progress to curb the federal deficit, concern that prices might rise more rapidly, and expectations that monetary policy would not accommow date rapid growth in money and credit.

In the Committee's discussion of the economic situation and outlook, members expressed concern that the current pace of the economic expansion, if maintained for long, would lead to growing imbalances, to price and wage pressures in some sectors of the economy and to continuation - against the background of persisting large federal deficits
- of exceptionally heavy credit demands. Consequently, the sustainability of the expansion would be jeopardized.

At the same time, several members observed that, in the

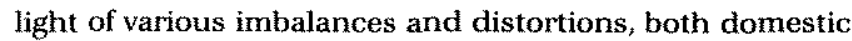
and international, the economy might be vulnerable to large and sudden increases in interest rates and pressures on financial markets. The emergence of strong business credit demands on top of a continuing large rate of increase in consumer and mortgage credit and massive Treasury financings accentuated these risks.

The point was also emphasized by some members that significant shortfalls in monetary growth might desirably lead to some easing of interest rate pressures. There was general acceptance of an approach that would take into account such factors as the apparent strength of economic activity and of inflationary pressures in any adjustment of the degree of reserve restraint. A number of members also called attention to the rate of credit growth, which had accelerated considerably in early 1984 and which appeared to be an important factor in recent interest rate increases.

with regard to preferences for the Committee's operational approach, there were some differences of view about whether the recent degree of reserve restraint should be maintained or altered in the period ahead, and under what conditions. Many felt that maintenance of something like the degree of restraint that had developed in recent days offered a reasonable prospect for achieving the monetary growth and financial market conditions that would foster a sustainable pace of economic expansion, help to contain inflation, and minimize the potential damage to interest sensitive sectors of the economy.

Other members of the Committee, viewing demand pressures on the economy as stronger and posing a more immediate threat of rising price pressures and growing imbalances, felt that some intensification in the degree of reserve restraint was called for at this time. This would, it was maintained, reduce the risk that much more vigorous restraint would be needed later, with sharply adverse consequences for sectors of the economy that were vulnerable to rising interest rates. These members were, nonetheless, concemed about moving too aggressively in the direction of greater restraint, given the sensitive state of domestic and international credit markets and uncertainties about the underlying strength of demand pressures.

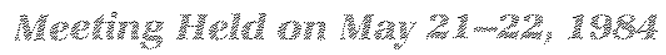

M1 changed little in April, but data available for early May suggested a considerable strengthening. Given the pickup in early May, it was estimated that growth of M1 since March was roughly in line with the $6^{1 / 2}$ percent annual rate of expansion sought by the Committee for the March-to June period. Expansion in M2 was at an annual rate of about $7^{1 / 4}$ percent in April, close to the rate specified by the Committee for the three month period, while growth in $\mathrm{M3}$, at an annual rate of $10^{3 / 4}$ percent in April, was well above its $81 / 2$ percent March-to-June growth path. 
Most of the members, as they had at previous meetings expressed concern that growing capacity constraints, declining unemployment, and the prospect of reduced productivity growth might be conducive to greater inflationary pressures over time.

A more optimistic view of the outlook for inflation emphasized the possibility of currently relatively favorable wagecost developments continting for some time.

In the view of most members, no significant change in policy - in either dinection - was desirable at this time in light of the performance of the economy, the behavior of the monetary aggregates, and conditions in financial markets Under present circumstances, it was argued, any significant further restraint would produce added strains in interestsensitive sectors of the economy such as housing and agriculture and would incur an undue risk of a pronounced effect on already somewhat unsettled financial markets with adverse effects on economic activity. At the same time, the apparent strength of the ongoing expansion and inflationary concerns argued against any significant easing. An argument advanced in favor of slightly greater restraint was that such a policy would tend to improve the prospects of achieving a desirable moderation in the rate of business expansion and progfess over time in containing inflation.

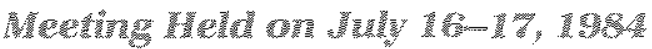

The members recognized that there were a number of threats to the realization of the relatively favorable economic developments implied by their projections and that the maintenance of a satisfactory economic performance for an extended period could only be assured by timely actions in a number of policy areas. Given the persisting strength of domestic demands, which had been growing faster than GNP as reflected in the widening deficit in external frade, several members indicated their concern about the risks that those demands might proceed too long at an unsustainable pace, with potentially adverse implications for inflationary pressures and for the continuation of the expansion itself. On the other hand, most members clearly did not want to rule out the possibility that relatively high interest rates, partly related strains in international and domestic financial markets, and cautionary attitudes that might be emerging in economic sectors such as housing might result in more substantial slowing than was typically indicated. Various imbalances and distortions in the economic and financial picture, notably the massive deficits in the federal budget and in the current account of the balance of payments, were also viewed as particular sources of concern.

In the course of discussion about the appropriate ranges for the aggregates, the members noted that in recent quarters the behavior of $M 1$ in relation to nominal GNP had been more consistent with previous cyclical patterns than had been the case during 1982 and early 1983 . As a result it was concluded that M1 should be given roughly equal weight with the broader monetary aggregates in the implementa- tion of monetary policy. However, the behavior of M1 as $w$ as that of the broader aggregates would still continue to appraised in light of developments in the economy a financial markets, the outlook for inflation, and rate of cre growth.

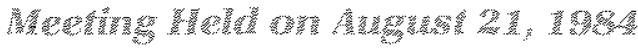

In the Committee's discussion of policy implementati for the weeks immediately ahead, a majority of the me bers expressed a preference for continuing to maint: about the current degree of restraint on reserve positions number of members, while finding the current approach policy implementation acceptable, nonetheless were $p$ pared to look toward some slight easing of reserve con tions, either currently or soon should monetary growth to pick up from recent trends. They believed that such approach would likely be consistent with attainment of 1 third-quarter objectives for monetary growth that had be set at the July meeting, given the shortfall in the aggrega since the meeting, and would also be consistent with sif of some weakening in the rate of economic growth relat to expectations. Moreover, in the view of at least some these members, some lessening in the degree of rese: restraint would appropriately tend to offset the unus pressures that had developed in the fedenal funds mar during June and July. Those pressures were not associal with any change in the degree of reserve restraint, but th appeared to reflect the emergence of more consemat reserve management attitudes on the part of banks. Otl members commented, however, that any active effort ease reserve conditions would be undesirable at prese and could well be misinterpreted, unless clearly related emerging weakness in monetary growth in the contex! appreciably slower-than-expected expansion in econor activity,

As compared with conditions at the time of the previc meeting, the monetary aggregates had weakened - $w$ M1, for example, closer to the middle of its longer-run rar - and there were more indications of a moderation in : expansion of economic activity. It was understood that $\dot{c}$ intermeeting adjustment in reserve pressures would not made automatically in response to the behavior of the mi etary aggregates, but would be undertaken only in the $c$ text of appraisals of the strength of economic activity a inflationary pressures, and evaluations of conditions in 1 mestic and international financial and banking markets a the rate of credit growth.

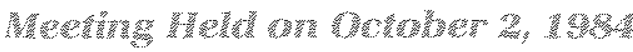

The information reviewed at this meeting indicated $t$ growth in real GNP had slowed appreciably in the th quarter from the annual rate of about $8^{1 / 2}$ percent recort in the first half of the year. The slowing was most markec final sales, which seemed to grow little during the quar while the rate of inventory accumulation appeared to $h$ accelerated. Thus far in 1984 , the rise in various measure: 
prices and wages appeared to be close to, or slightly below, the pace in 1983.

As the intermeeting period progressed, incoming information pointed to continuing substantial shortfalls in growth of the monetary aggregates relative to the Committee's expectations for the third quarter. Growth of $M 1$ in August tumed out to be quite small, and while there appeared to be a moderate acceleration in September, expansion over the three-month period from June to September was running well below the Committee's expectations. Growth of M2 and M3 also appeared to have picked up in September after expanding at relatively sluggish rates over the previous two months, but growth in these broader aggregates over the summer was also lower than expected.

Against the background of monetary growth that was weaker than anticipated, evidence of a slowing pace of economic advance, and a rapidly rising dollar in foreign exchange markets, open market operations were conducted, as the intermeeting period progressed, so as to lessen pressures on bank reserve positions.

The Committee's discussion of the economic situation and outlook focused on the implications of recent indications of appreciably slower growth in the context of an economic outlook that was already complicated by unusu* ally large, sustained federal deficits, a strengthening dollar on exchange markets, and sensitive domestic and international financial markets. Many members commented that the economy appeared to be adjusting to a reduced, but potentially more sustainable, rate of expansion and that the moderation was likely in turn to be associated with relatively subdued rates of wage and price inflation, It was noted that many past expansions had been interrupted by a "pause" in the rate of economic growth. Although no one could say with certainfy whether this most recent experience represented a "pause" and, if so, how long it would last, a number of members believed that a modest rebound was a likely prospect for the next quarter or two followed by some moderation in the rate of expansion later. Other members gave more weight to elements of slowing in the current economic situation, and they saw a greater likelihood of sluggish growth in the period ahead.

Several members referred to the progress that had been made in containing inflation, although some threats to future progress remained, and a few members commented that inflation was still the main economic problem for the longer run. In this connection, concern was expressed that too strong a resurgence in spending, though not viewed as a likely development, would intensify inflationary pressures and would set in motion forces, which could threaten the sustainability of the expansion itself. Moreover, as the foreign exchange value of the dollar rose, the possibility increased that a subsequent decline in the exchange rate could be precipitous when it occurred, which would exert significant upward pressures on domestic prices.

In the Committee's discussion of policy implementation for the weeks immediately ahead, most of the members favored directing open market operations, at least initially, toward maintaining the lesser degree of reserve restraint that had been sought in recent weeks. Such an approach to policy was expected to be associated with expansion in the monetary aggregates from September to December at rates that were somewhat above those experienced over the third quarter, especially in the case of M1. It was noted in this connection that the degree of reserve restraint had been eased appreciably in recent weeks and that any further easing should be contingent upon clear evidence of further weakness in the monetary aggregates and the economy.

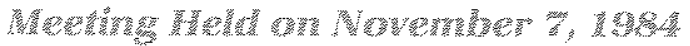

Growth in the monetary aggregates strengthened in September from the sluggish pace in August. But data available for October indicated that M1 declined during the month; as a result, $M 1$ was running well below the Committee's expectations for growth in the fourth quarter. Expansion in M2 was also below the Committee's expectations, although to a much lesser extent, while growth in $\mathrm{M} 3$ appeared to be at a pace somewhat above the Committee's expectations.

Toward the end of the intermeeting interval, open market operations were conducted to further reduce pressures to borrow in recognition of the extended weakness of $M 1$, and to a degree $\mathrm{M} 2$, against the background of incoming economic and financial indicators suggesting, on balance, a marked slowing in the pace of economic expansion. As a result of these developments, together with market expectations of monetary easing and a drop in other short-term rates, the federal funds rate moved down irregularly from around 11 percent just before the October meeting to around 10 percent most recently, with trading on several days in the area of $9^{1 / 2}$ percent or below. At the same time, other short-term rates fell about $1^{1 / 4}$ to $1^{1 / 2}$ percentage points over the period. Long-term rates on taxable securi ties generally declined about $3 / 4$ percentage point, responding in part to expectations of an improved outlook for inflation as oil prices weakened as well as to the signs of moderating economic expansion. Most major banks reduced their "prime" lending rate in several steps from 123/4 percent to 12 percent, and a few banks lowered their rate to $11^{3 / 4}$ percent.

In the Cummittee's discussion of the economic situation and outlook, members commented that a mixed pattern of developments had fostered increased uncertainty about the prospects for economic activity. While most agreed that the staff projection of moderate growth in real GNP was a reasonable expectation, much of the discussion focused on the risks of an appreciable deviation from the projection under prevailing circumstances. A few members believed that the chances of a deviation were tilted in the direction of somewhat faster expansion than the staff was projecting, but others expressed concern that the rate of growth might remain quite sluggish in the near term with some possibility of a rise in the rate of unemployment.

The outlook for consumer expenditures was cited as a key area of uncertainty. Several members felt that evidence 
of general improvement was still lacking after the summer slowdown. It was noted, however, that a number of retailers expected sales to improve in conjunction with the forthcoming holiday season. A failure of consumer spending to revive in line with expectations would have adverse implications for economic growth beyond the fourth quarter, as it would reinforce a recent tendency by businesses to curb their accumulation of inventories or possibly induce them to attempt to reduce previously acceptable inventory levels.

Members who were relatively optimistic about the prospects for economic activity noted the favorable impact that recent declines in interest rates were likely to have on interest-sensitive sectors of the economy such as housing. They also noted that the basic forces that had given impetus to the expansion over the last several quarters were still largely present. These included rising consumer incomes, a high: degree of consumer confidence and relatively strong financial positions, a subdued rate of inflation, a favorable outlook for investment in plant and equipment, and a large federal deficit that, at least in the short run, provided a strong stimulus to the expansion. A number of members observed, however, that while underlying factors favored sustained expansion, the timing of a pickup in economic growth following the "pause" experienced in recent months remained uncertain and growth might well remain relatively sluggish in the current quarter.

Most members felt that the potential for a sharp upward surge in business activity had diminished appreciably for the time being and with it the possible need for a near-term reversal of easing steps alfeady taken. On balance, nearly all of the members favored further easing from the reduced degree of reserve restraint sought recently. While preferences with regard to the extent of such easing differed somewhat, a majority urged that the lesser restraint be implemented in limited steps, pending an evaluation of its impact on financial markets and of incoming information on the economy and the monetary aggregates. A number of members, who suggested slightly more aggressive steps, stressed that the risks of stimulating an intensification of inflationary pressures were relatively small under foreseeable circumstances and that, on balance, more weight needed to be given to the risks of inadequate monetary and economic growth. With regard to the latter, some members noted that the economy appeared to have the capacity for somewhat faster expansion than was generally expected without generating significantly greater inflationary pressures.

In the course of the Committee's discussion, the members generally agreed that under prevailing economic and financial conditions, policy implementation should be particularly alert to the possible need for adjustment toward lesser restraint. It was felt that any such adjustment should be made promptly, although not automatically, depending on the behavior of the monetary aggregates and continuing indications of relatively sluggish economic activity. In this view, policy implementation should be relatively tolerant, for a time, of a substantial rebound in monetary growth, given the unexpected weakness of M1 in October. Any adjustment of operations in a tightening direction shotld also depend upon clear evidence of substantial strengthening in economic activity.

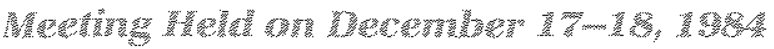

The information reviewed at this meeting indicated a mixed pattern of developments, with some sectors showing a pickup from the lull of earlier months. On balance, however, economic activity appeared to be expanding in the current quarter at a rate approximating the considerably reduced pace recorded in the third quarter. Broad measures of prices generally continued to increase at rates close to those in 1983 .

Open market operations over the intermeeting interval were directed at achieving some reduction in pressures on bank reserves against the background of lagging growth in the narrow money supply, generally sluggish expansion in the economy, subdued inflation, and continued strength of the dollar in foreign exchange markets. The average level of borrowing by depository institutions at the discount window moved down on balance over the period, and in November nonborrowed and total reserves increased at annual rates of about $17^{1 / 2}$ and $11^{1 / 4}$ percent respectively. The decline in borrowing, along with a reduction in the discount rate from 9 to $81 / 2$ percent on November 21, was associated with a drop in the federal funds rate from the $9 \mathrm{t} / 2$ to 10 percent area at the time of the November FOMC meeting to around $8^{3 / 4}$ percent recently, with trading on the days immediately preceding this meeting somewhat below that level. Other short-term interest rates also moved down, declining about 50 to 90 basis points; intermediate-term rates fell about 45 to 65 basis points, while most long-term rates declined only modestly.

In the Committee's discussion of the economic situation and outlook, the members differed to some extent on the prospects for economic activity in $\mathbf{1 9 8 5}$, but they generally agreed that underlying economic conditions favored further moderate growth during the year, especially in the context of a stimulative fiscal policy and the decline in interest rates that had occurred. While various measures of economic activity continued to indicate a mixed pattern of developments, some recent information suggested a less sluggish overall performance than earlier.

The members continued to give considerable emphasis to the many risks that could lead to an unexpected outcome, especially in view of potential complications associated with massive and sustained federal deficits and very large imbalances in the nation's foreign trade. Other areas of uncertainty related to various financial strains or other problems in several sectors of the economy, including energy-related industries and especially agriculture which was experiencing serious difficulties in many parts of the country. It was also noted that the recent tax proposals of the U.S. Treasury might tend to alter business spending plans in uncertain ways as the likelihood of implementation of various elements of the proposals was assessed. 
As they had at previous meetings, the members gave a good deal of attention to the effects of the continuing strength of the dollar in foreign exchange markets. The related surge in imports was having a very negative impact on production in many domestic industries, while expansion in exports was being curbed by the appreciated value of the dollar as well as by relatively slow economic growth abroad. Some members commented that they saw little or no prospect for significant improvement in the trade balance in 1985.

The members continued to regard the outlook for inflation as relatively favorable in the sense that a moderate expansion in economic activity was not seen as likely to be associated with renewed upward pressures on wages and prices or, absent a sharp decline in the dollar, strong new price pressures from other sources. Members noted that prices of sensitive commodities were still declining and that there appeared to have been a downward shift in in- flationary expectations in recent months, with favorable implications for future progress in containing wage and price increases. Indeed, a number of members commented that somewhat faster economic growth than was generally expected at this time might also be compatible with little or no additional inflationary pressures in 1985. At the same time, if was emphasized that the rate of inflation was still too high and needed to be reduced over time.

During the Committee's discussion of policy implementation for the intermeeting period ahead, most of the members expressed a preference for directing open market operations toward some further easing of reserve conditions to encourage satisfactory growth in $M 1$ and to improve the prospects for economic expansion in 1985. The views of these members differed to some extent on the degree of easing that should be sought. A few members, though, wanted essentially to maintain, pending new developments, the lesser degree of reserve restraint that had been achieved recently. 